\title{
Tasawuf Sunda dan Warisan Islam Nusantara: Martabat Tujuh dalam Dangding Haji Hasan Mustapa (1852-1930)
}

\author{
Jajang A Rohmana ${ }^{1}$
}

\begin{abstract}
Abstrak
Paper ini membahas martabat tujuh dalam puisi dangding sufistik Haji Hasan Mustapa. Ia merupakan salah satu penerus tradisi tasawuf Nusantara dari Jawa Barat yang menulis lebih dari sepuluh ribu bait dangding. Tema martabat tujuh merupakan poros inti pembahasan dalam hampir keseluruhan puisi dangdingnya. Berbagai kesalahpahaman dan kesulitan para sarjana dalam memahami puisi Mustapa kiranya dilatarbelakangi keterbatasan pengetahuan atas ajaran ini. Kajian ini menggunakan pendekatan interteks atas sejumlah puisi Mustapa yang bertema sama. Kajian ini memfokuskan pada tiga hal: martabat tujuh dalam tradisi tasawuf Nusantara, Mustapa dan posisi dangding-nya dalam sastra Sunda, serta tema martabat tujuh sebagai inti puisinya. Mustapa kiranya dipengaruhi ajaran wahdatul wujud terutama melalui kitab Tuhffah-nya AlBurhanfuri. Meski demikian, ia berusaha menjejakkannya dalam latar kekayaan budayanya. Ia menginterpretasikan martabat tujuh, bukan semata-mata sebagai sintesis tajalli Ilahi, tetapi juga merupakan hasil upaya manusia dalam meningkatkan martabat rohani untuk pulang ke tempat di mana ia berasal (nepi kana urut indit). Karenanya tidak tepat bila ia dianggap menyimpang dari nilainilai ortodoksi Islam. Ia berada pada arus utama tasawuf Nusantara yang cenderung rekonsiliatif. Signifikansi Mustapa terletak pada kreatifitasnya dalam menggunakan banyak metafor budaya Sunda termasuk dalam menafsir ajaran martabat tujuh. Ia misalnya, menggunakan metafor tubuh (balung, daging, sungsuam, getih), makanan (rujak), sungai (leuwi), dan bukit (lamping) untuk menggambarkan proses panjang dalam meracik asal alam kesejatian. Kajian ini signifikan dalam memperkuat tesis jaringan ulama Nusantara dalam bentuk artikulasi tasawuf lokal Sunda. Sebuah tafsir lain atas martabat tujuh yang muncul dalam rahim alam pikiran budaya Sunda.
\end{abstract}

Kata kunci: martabat tujuh, dangding, tasawuf, Sunda

\begin{abstract}
This paper discusses the dignity seven in metrical poetry Sufi Hasan Haji Mustapa. He is one of the successors of Sufism archipelago from West Java who wrote more than ten thousand metrical stanza. He was in the mainstream Sufism archipelago tend reconciliatory. Mustapa significance lies in creativity in using many metaphors Sundanese culture including seven in interpreting the teachings of dignity. He for instance, uses the metaphor of the body (bone, meat, sungsuam, getih), food (salad), rivers (Leuwi), and Hill (lamping) to describe the lengthy process of preparing the authenticity of natural origin. This study is significant in strengthening the network of scholars Nusantara thesis in the form of Sufism articulation of local Sundanese.
\end{abstract}

Keyword: dignity seven, metrical, Sufism, Sundanese

\footnotetext{
${ }^{1}$ UIN Sunan Gunung Djati Bandung
} 


\section{A. Pendahuluan}

Haji Hasan Mustapa (1852-1930) merupakan salah satu penerus tradisi tasawuf Nusantara dari tatar Sunda (Jawa Barat). Ia merupakan sastrawan Sunda terbesar yang menulis lebih dari sepuluh ribu bait puisi bermatra (dangding atau guguritan) berbahasa Sunda. ${ }^{2}$ Salah satu inti pembahasan dalam puisi sufistiknya adalah martabat tujuh. Sebuah tema populer dalam tradisi keilmuan Islam Nusantara. Tema yang umumnya ditemukan dalam naskah keagamaan terutama di Aceh, Palembang, Buton, Jawa, Sunda, Banjar dan lainnya.

Ajaran martabat tujuh merupakan salah satu tema penting yang menjadi poros hampir keseluruhan tema puisi dangding Mustapa. Kiranya sulit memahami pikiran Mustapa tanpa berpijak pada ajaran ini. Terlebih Mustapa juga menulis karya khusus berjudul Aji Wiwitan Martabat Tujuh. ${ }^{3}$ Inilah yang menjadi salah satu alasan mengapa dibanding anekdotnya, kandungan puisi Mustapa sulit dipahami orang Sunda sebagaimana dikeluhkan banyak sastrawan Sunda. ${ }^{4}$ Bahkan Millie mengaku merasa tidak sanggup mengarungi dunia Mustapa dan membiarkannya menggaruk-garuk kepala ketika berhadapan dengan dangding-nya. ${ }^{5} \quad$ Akibatnya berbagai kesalahfahaman pun muncul hingga mengundang reaksi negatif seperti tampak pada jawaban Mustapa atas

2 Jajang Jahroni, "The Life and Mystical Thought of Haji Hasan Mustafa (1852-1930)," Thesis, Leiden University, 1999, hlm. 79.

3 Haji Hasan Mustapa, Adji Wiwitan Martabat Tudjuh, Kenging ngumpulkeun sarta ngatur Wangsaatmadja sareng para panitiana, n.p. n.d.

4 Ajip Rosidi, Ngalanglang Kasusastran Sunda, Jakarta: Pustaka Jaya, 1983, hlm. 56-57.

5 Julian Millie, “Arriving at the Point of Departing, Recent Additions to the Hasan Mustapa Legacy,” BKI 170 (2014), hlm. 110-111. 'surat kaleng' yang diduga dikirimkan oleh Sayyid Uthman bin Yahya (18221913), ulama Betawi jaman kolonial. ${ }^{6}$

Salah satu kelebihan puisi Mustapa tentang martabat tujuh adalah pengungkapannya yang dijejakkan dalam alam pikiran Sunda. Berbagai metafor alam kesundaan digunakan untuk mengungkapkan perasaannya dalam bingkai martabat tujuh. Bahasa simbol kiranya mampu mewakili perasaan spiritual mistis yang dialami oleh siapapun yang merasakan kedekatannya dengan Tuhan. ${ }^{7}$ Sebagaimana Hamzah Fansuri dalam tradisi sastra Melayu atau Ronggowarsito melalui sastra Jawa, Mustapa menuangkan perasaannya melalui tradisi sastra Sunda. Sebuah kreatifitas literer bagaimana tradisi sufistik Nusantara diserap dan diungkapkan dalam bahasa dan sastra Sunda.

Kajian ini signifikan untuk menjawab kesulitan orang Sunda terutama sastrawan Sunda dalam memahami puisi dangding Mustapa. Rosidi, Iskandarwassid, Rusyana dan Ekadjati misalnya, cenderung menyajikan dan menilainya dari sisi sastra Sunda. ${ }^{8}$ Secara lebih luas, kajian ini memperkuat tesis tentang peran

\footnotetext{
${ }^{6}$ Ajip Rosidi, Haji Hasan Mustapa jeung Karyakaryana, Bandung: Pustaka, 1989, hlm. 88 dan 434. Tentang Sayyid Uthman, lihat misalnya Nico Kaptein, "Sayyid Uthman On the Legal Validity of Documentary Evidence," Bijdragen tot de Taal-, Land- en Volkenkunde 153 (1997), no: 1, Leiden, hlm. 85-102.

${ }^{7}$ Idries Shah, The Sufis (London: The Octagon Press, 1977), hlm. x.

${ }^{8}$ Ajip Rosidi, Haji Hasan Mustapa jeung Karyakaryana (1989); Yus Rusyana dan Ami Raksanegara, Puisi Guguritan Sunda, Jakarta: Pusat Pembinaan dan Pengembangan Bahasa Depdikbud, 1980; Iskandarwassid et.al., Naskah Karya Haji Hasan Mustapa, Bandung: Proyek Sundanologi, 1987; Edi S. Ekadjati, Empat Sastrawan Sunda Lama, Jakarta: Depdikbud, 1994.
} 
jaringan ulama sufi dalam proses Islamisasi di Asia Tenggara. ${ }^{9}$ Ia terutama mengkonfirmasi tesis Johns tentang kuatnya pengaruh Tuhfah karya al-Burhanfuri terhadap tradisi sufistik Nusantara. $^{10} \quad$ Christomy sudah membuktikan pengaruhnya dalam tradisi tasawuf di Jawa Barat terutama melalui doktrin metafisika tarekat Shattariyah di Pamijahan yang merujuk pada ajaran martabat tujuh Syeikh Abdul Muhyi (1640-1715). ${ }^{11}$ Mustapa kiranya dekat dengan tradisi Shattariyah tersebut.

Sosok Mustapa dan karyanya sudah banyak diperkenalkan dan dipublikasikan terutama oleh Ajip Rosidi. ${ }^{12}$ Pemikiran tasawuf Mustapa pun sudah cukup banyak dikaji. Namun, ajaran martabat tujuh yang terdapat

9 Azyumardi Azra, The Origins of Islamic Reformism in Southeast Asia: Networks of Malay-Indonesian and Middle Eastern 'Ulamā', in the seventeenth and eighteenth centuries, Honolulu: ASAA-Allen \& Unwin and University of Hawai'i Press, 2004.

${ }^{10}$ A.H. Johns, The Gift Adressed to the Spirit of the Prophet, Canberra: Center of Oriental Studies A.N.U, 1965.

11 Tommy Christomy, Signs of the Wali: Narratives at the Sacred Sites in Pamijahan, West Java. Canberra: ANU E Press, 2008.

${ }^{12}$ Wendy Solomon, "Text and Personality: Ajip Rosidi in Search of Haji Hasan Mustapa," Indonesia Circle. School of Oriental \& African Studies. Newsletter, 14:41, 1986, hlm. 11-27. Publikasi dangding Mustapa misalnya terdapat dalam Haji Hasan Mustapa, Dangding Djilid Anu Kaopat (1960); Haji Hasan Mustapa, Gendingan Dangding Sunda Birahi Katut Wirahmana Djilid A (1976); Haji Hasan Mustapa, Seri Guguritan Haji Hasan Mustapa (Asmarandana $\mathrm{Nu}$ Kami, Kinanti Kulu-kulu, Sinom Wawarian, Dangdanggula Sirna Rasa, Sinom Barangtaning Rasa) (Bandung: Kiblat, 2009); Ajip Rosidi, Haji Hasan Mustapa jeung Karya-karyana (1989); Iskandarwassid, Ajip Rosidi, Josep CD., Naskah Karya Haji Hasan Mustapa, (Bandung: Proyek Sundanologi, 1987); Yus Rusyana dan Ami Raksanagara, Puisi Guguritan Sunda, (Jakarta: Pusat Pembinaan dan Pengembangan Bahasa Depdikbud, 1980); Edi S. Ekadjati, Empat Sastrawan Sunda Lama (1994). dalam banyak dangding-nya belum diulas secara mendalam. Gibson misalnya, yang mengkaji karya prosa Mustapa, Gelaran Sasaka di Kaislaman, menyebut martabat tujuhnya sebagai lanjutan dari fase-fase dalam Gelaran, yakni "Islam-iman-soleh-ihsan-sahadahsidikiyah-kurbah."13 Kajian lainnya dilakukan Jahroni dan beberapa sarjana lain tentang ajaran martabat tujuh Mustapa yang didasarkan pada karya prosanya, Aji Wiwitan Martabat Tujuh. ${ }^{14}$ Sayang kajian tersebut tidak memfokuskan pada puisi dangding Mustapa. Padahal di dalamnya ditemukan nuansa berbeda tentang martabat tujuh dengan metafor, simbol dan alam pikiran Sunda. Kajian ini memfokuskan nuansa lain martabat tujuh di Nusantara. Sebuah tafsir martabat tujuh dalam bingkai alam budaya Sunda dengan dangding sebagai wadahnya. Kajian menggunakan pendekatan interteks yang merujuk pada sejumlah karya dangding Mustapa, baik berupa manuskrip maupun publikasi transkripsinya.

\section{B. Pembahasan}

\section{Martabat Tujuh di Nusantara}

Ajaran martabat tujuh merupakan salah satu doktrin terpenting dalam mistisisme Islam. Ia berusaha memecahkan problem filosofis tentang relasi antara Yang Mutlak dan yang relatif, Yang Esa dengan yang banyak. Ia

13 Ahmad Gibson Albustomi, Filsafat Manusia Sunda: Kumpulan Esai HHM, Teosofi dan Filsafat, Bandung: Skylart Publisher, 2012, hlm. 5.

14 Jajang Jahroni, "The Life and Mystical Thought of Haji Hasan Mustafa (1852-1930)," hlm. 8298; Agus Abdurrahman, "Martabat Tujuh Haji Hasan Mustapa," Skripsi, IAIN Sunan Gunung Djati Bandung, 2000; Wiwi Siti Sajaroh, Konsep Martabat Tujuh Haji Hasan Mustapa, Laporan Penelitian, LP2M UIN Jakarta, 2013. 
berakar dari bantahan atas doktrin 'penciptaan dari tiada' (creatio exnihilo, al-khalq min al-'adam). ${ }^{15}$ Para penganut tasawuf filosofis mengajukan teori manifestasi Tuhan (tajalli). Sebuah teori penciptaan yang berasal dari manifestasi esensi diri-Nya. Tuhan menciptakan makhluk-Nya sebagai objek cinta-Nya. Makhluk-Nya tidak muncul dari ketiadaan, tetapi melalui determinasi sifat Tuhan terhadap esensi diri-Nya sehingga terwujudlah makhluk sebagai manifestasi-Nya. Manifestasi tersebut terjadi melalui hirarki wujud yang terdiri dari tujuh tingkatan wujud sehingga disebut martabat tujuh (marātib al-sab, martabat pitu): ahadiyat, wahdat, wahidiyat, alam arwah, alam mithal, alam ajsam, dan insan kamil.

Muhammad ibn Fadhlillah AlBurhanfuri (1545-1620) merupakan perintis ajaran ini. Ia menuangkannya dalam Tuhfah al-Mursalah ilä Rüh alNabi (ditulis 1590). Sebuah teks tasawuf paling penting abad ke-17 yang menyebar terutama di lingkungan tarekat Shattariyah. Ia sebenarnya berupa penjelasan singkat seputar keberlimpahan ajaran metafisika Ibn 'Arabi dan Al-Jili tentang martabat wujud. ${ }^{16}$ Karyanya merepsesentasikan sebuah upaya mengendalikan kecenderungan ekstrem kelompokkelompok mistik tertentu di India dan memastikan untuk berpedoman dan mempraktekkan elemen dasar ajaran Islam. Bisa dikatakan Tuhfah merepresentasikan tradisi ortodoksi sufistik. $^{17}$ Ini dibuktikan dengan komentar Al-Burhanfuri sendiri atas

${ }^{15}$ Harun Nasution, Falsafah dan Mistisisme dalam Islam, Jakarta: Bulan Bintang, 1973, hlm. 22-23.

16 Yunasril Ali, Manusia Citra Ilahi, Pengembangan Konsep Insan Kamil Ibn 'Arabi oleh al-Jili (Jakarta: Paramadina, 1997), hlm. 129.

17 A.H. Johns, The Gift Adressed to the Spirit of the Prophet, hlm. 5.
Tuhfah, yakni Al-Haqiqah alMuwāfaqah li al-Sharì'ah. Ia menjelaskan posisinya dalam melakukan rekonsiliasi tasawuf dengan syariat yang sama sekali berbeda dengan dugaan banyak orang. ${ }^{18}$

Tuhfah sampai di Nusantara setelah komunitas Jawi asal Aceh melakukan kontak dengan pengikut Shattariyah asal Gujarat di Madinah sekitar abad ke-17. ${ }^{19}$ Beberapa pengikutnya juga kemudian berkunjung ke Aceh dan bertemu dengan Shamsuddin Al-Sumatra'i (1550?1630). ${ }^{20}$ Shamsuddin dianggap sebagai "ulama pertama" yang mengembangkan ajaran martabat tujuh di MelayuNusantara. Ia menerima ajaran martabat tujuh melalui Tuhfah yang dikirim dari India ke Aceh. $^{21}$ Meski Shamsuddin mengikuti ajaran pendahulunya, Hamzah Fansuri (w. 1590?), tetapi tidak ada bukti tertulis bahwa Hamzah menggunakan ajaran martabat tujuh. ${ }^{22}$ Meski demikian, keduanya sama-sama dianggap sebagai penganut mistik

${ }^{18}$ Iin Suryaningsih, "Al-Haqīiah al-Muwāfaqah li al-Shari' ah: al-Tașāluh bayn al-Tașawwuf wa alShari'ah bi Nusantara fì al-Qarn al-Sādis 'Ashr al-Milādi," Studia Islamika, Vol. 20, No. 1, 2013, hlm. 97-127.

${ }^{19}$ Werner Kraus, "The Shattariya Sufi Brotherhood in Aceh," dalam Arndt Graf et.al, Aceh History, Politics and Culture, Singapore: Iseas, 2010, hlm. 212.

20 A.H. Johns, "Reflections on the Mysticism of Shams al-Din al-Samatra'i (1550?-1630), dalam Jan van der Putten and Mary Kilcline Cody ed., Lost Times and Untold Tales from the Malay World, Singapore: NUS Press, 2009, hlm. 152.

21 A.H. Johns, "Islam in Southeast Asia: Reflections and New Directions," Indonesia, 19, 1975, hlm. 45.

22 Oman Fathurahman, "Sejarah Pengkafiran dan Marginalisasi Paham Keagamaan di Melayu dan Jawa," Analisis, Vol. XI, No. 2, Desember 2011, hlm. 454-458. 
heterodoks oleh Nuruddin Al-Raniri (w. 1658). ${ }^{23}$

Selain Shamsuddin, para ulama sufi asal India di Madinah juga melahirkan ulama terkenal lainnya, Ahmad Al-Qushashi (1583-1660). Melalui Al-Qushashi, ajaran Shattariyah mengalami reorientasi ke arah rekonsiliasi mistis dan syariat (neosufisme) ${ }^{24}$ Ia dianggap sebagai tokoh utama dalam transmisi ajaran Shattariyah yang lebih moderat ke berbagai penjuru dunia. Dua murid utamanya yang berjasa membawa ajaran tersebut ke Nusantara adalah Ibrahim Al-Kurani (1616-1690) dan Abdurrauf bin Ali Al-Jawi atau Al-Sinkili (16151693). ${ }^{25}$

Al-Kurani memiliki kedudukan penting terutama melalui karyanya, Ithă $\bar{f}$ al-Dhaki. Sebuah komentar penting atas kitab Tuhfah yang ditulis sekitar 1665 . Kitab ini merupakan jawaban atas permintaan Komunitas Jawi di Haramayn atas kontroversi faham wahdatul wujud dan martabat tujuh di Aceh. Ia memberikan tafsir rekonsiliasi atas pemahaman tasawuf yang dianggap heterodoks, panteis dan dianggap mengesampingkan syariat. ${ }^{26}$

23 Azyumardi Azra, The Origins of Islamic Reformism in Southeast Asia, hlm. 53.

24 Oman Fathurahman, Tarekat Syattariyah di Minangkabau. Jakarta: Prenada Media, EFEO, PPIM, KITLV, 2008, hlm. 32.

${ }^{25}$ Tentang tarekat Shattariya dari Abdullah Shattar hingga Al-Qushashi, Al-Kurani dan Al-Sinkili, lihat Werner Kraus, "The Shattariya Sufi Brotherhood in Aceh," hlm. 206-211; J. Spencer Trimingham, The Sufi Orders in Islam, Oxford: Clarendon Press, 1977, hlm. 97-98.

26 Oman Fathurahman, Ithaf Al-Dhaki, Tafsir Wahdatul Wujud bagi Muslim Nusantara, Bandung: Mizan, 2012, hlm. 6; Oman Fathurahman, "Ithaf al-Dhaki by Ibrahim AlKurani: A Commentary of Wahdat al-Wujud for Jawi Audience," Archipel 81, Paris, 2011, hlm. 177-198.
Namun dibanding Al-Kurani, Abdurrauf kiranya dianggap paling otoritatif dalam menyebarkan ajaran Shattariyah di Nusantara abad ke-17. Ia merupakan khalifah utama Shattariyah di kawasan ini. Hampir semua silsilah Shattariyah di Nusantara melalui jalur dirinya. Murid-muridnya tersebar di Sumatera, Jawa, Sulawesi hingga Semenanjung Melayu (Trengganu). Beberapa ulama di antaranya menulis karya yang secara eksplisit menunjukkan pengaruh Tuhfah dan martabat tujuh, di antaranya Abdul Shamad Al-Falimbani, Daud Al-Fatani (1769-1847), dan Muhammad Nafis Al-Banjari. ${ }^{27}$ Bahkan di Buton Sulawesi Tenggara, ajaran ini dijadikan landasan dalam praktek politik kekuasaan sultan dan pejabat istana. ${ }^{28}$ Namun dari sekian banyak muridnya, Syeikh Burhanuddin (1646-1692) dari Ulakan Sumatera Barat dan Syeikh Abdul Muhyi (1640-1715) dari Pamijahan Jawa Barat cenderung sangat menonjol. Abdul Muhyi dianggap paling banyak berperan dalam penyebaran tarekat Shattariyah dan martabat tujuh di Jawa dan tatar Sunda dengan tanpa adanya pelucutan ajaran wahdatul wujud sebagaimana di Minangkabau. ${ }^{29}$

${ }^{27}$ Muhammad Chatib Quzwain, Mengenal Allah: Suatu Studi Mengenai Ajaran Tasawuf Syeikh Abdus Samad Al-Falimbani, Jakarta: Bulan Bintang, 1983; Francis R. Bradley, "Sheikh Da'ud al-Fatani's Munyat al-Musalli and The Place of Prayer in 19th-Century Patani communities," Indonesia and the Malay World, DOI:10.1080/13639811.2013.798072, hlm. 1-17; Abdul Muthalib, "The Mystical Thought of Muhammad Nafis Al-Banjari: An Indonesian Sufi of the Eighteenth Century," Thesis, McGill University Montreal Canada, 1995.

${ }^{28}$ Abdul Rahim Yunus, "Nazariyat Martabat Tujuh fi Nizam al-Mamlakah al-Butaniyyah," Studia Islamika, Vol. 2, No. 1, 1995, hlm. 93-110.

29 Oman Fathurahman, Tarekat Syattariyah di Minangkabau, hlm. 35, 91-98. Lihat juga Mu'jizah, Martabat Tujuh: Edisi Teks dan Pemaknaan Tanda serta Simbol, Jakarta: 
Di tanah Jawa, martabat tujuh kiranya tidak hanya tersebar di kalangan penganut tarekat Shattariyah, tetapi juga tarekat lainnya seperti Qadiriyah Naqsabandiyah dengan pendekatan multi tarekat sebagai salah satu ciri reformisme neo-sufisme abad $19 .{ }^{30}$ Dalam tradisi sastra Kraton Jawa abad ke-18 dan 19, luasnya pengaruh martabat tujuh dalam beragam tarekat juga menjadi salah satu tema penting. ${ }^{31}$ Berbagai elemen santri dalam Serat Centini menunjukkan adanya upaya konsiliasi dan harmonisasi antara mistisisme Jawa tradisional dan legalistik Islam ortodoks. ${ }^{32}$ Ricklefs menyebutnya sebagai bentuk sintesis mistik. Mengalami kesulitan untuk memaparkan doktrin sufi terkait tujuh tahapan emanasi, penulisnya memanfaatkan metafor Hindu-Jawa tentang hubungan Wisnu dan Kresna. Sebuah kesadaran identitas sebagai seorang Muslim sekaligus Jawa. ${ }^{33}$ Kecenderungan sintesis mistik ini juga tampak pada Serat Cebolek dan Serat Dewa Ruci. ${ }^{34}$ Begitu pun Wirid Hidayat Jati karya Ronggowarsito juga menunjukkan pengaruh martabat tujuh. Ia menunjukkan perpaduan antara martabat tujuh dengan tradisi kejawen

Penerbit Djambatan dan Yayasan Naskah Nusantara, 2005.

30 Michael Laffan, The Makings of Indonesian Islam, Orientalism and the Narration of a Sufi Past, Princeton: Princeton University Press, 2011, hlm. 153-154.

31 P.J. Zoetmulder, Manunggaling Kawula Gusti, Pantheisme dan Monisme dalam Sastra Suluk Jawa. terj. Dick Hartoko. Jakarta: Gramedia Pustaka Utama, 1991, hlm. 127 dan 368.

32 S. Soebardi, "Santri-Religious Elements as Reflected in the Book of Centini," Bijdragen tot de Taal-, Land-en Volkenkunde 127 (1971), No: 3, Leiden, hlm. 349.

33 M. C. Ricklefs, Mengislamkan Jawa, terj. FX. Dono Sunardi dan Satrio Wahono, Jakarta: Serambi, 2013, hlm. 36-37.

34 S. Soebardi, The Book of Cebolek. Leiden: KITLV-The Hague-Martinus Nijhoof, 1975. seperti Dewa Ruci. ${ }^{35}$ Begitu pun, Suluk Wujil yang dihubungkan dengan Sunan Bonang, mengambil beberapa doktrin dalam martabat tujuh. ${ }^{36}$

Di Priangan abad ke-20, pengaruh martabat tujuh juga kemudian menyebar dalam bentuk wawacan, sebuah cerita yang dikarang menggunakan pupuh layaknya dangding. Wawacan MusliminMuslimat misalnya, menunjukkan pengaruh martabat tujuh di dalamnya. ${ }^{37}$ Selain itu, ajaran ini kiranya juga dijadikan lensa pembacaan spiritual atas sejumlah legenda yang disebut Mustapa sebagai pasulukan Pasundan, seperti Mundinglaya Di Kusumah, Lutung Kasarung dan lainnya. HR. Hidayat Suryalaga (1941-2011) kiranya memperjelas lensa martabat tujuh ini dengan menyebutnya sebagai "sapta mandala panta-panta." 38

Mustapa yang hidup di awal abad ke-20 kiranya terhubung dengan tradisi tarekat Shattariyah di tatar Sunda. Ia diduga memiliki silsilah tarekat Shattariyah yang terhubung dengan Abdul Muhyi. Karya puisi dangding sufistik dan karya prosanya tentang martabat tujuh tidak bisa dilepaskan dari latar karirnya yang memungkinkan bersentuhan dengan teks dan tradisi

35 Simuh. Mistik Islam Kejawen Raden Ngabehi Ranggawarsita. Jakarta: UI-Press, 1988, hlm. 320-321; Simuh, "Aspek Mistik Islam Kejawen dalam 'Wirid Hidayat Jati,' dalam Ahmad Rifa'i Hasan, ed., Warisan Intelektual Islam Indonesia Telaah atas Karya-Karya Klasik, Bandung: Mizan, 1992, hlm. 68-69.

${ }^{36}$ G. Drewes, "Javanese Poems dealing with or attributed to the Saint of Bonan, Bijdragen tot de Taal-, Land-en Volkenkunde 124 (1968), No: 2, Leiden, hlm. 213.

37 Ruhaliah, "Analisis Struktur dan Nilai Budaya Naskah Sunda," Jurnal Sonagar, Vol. 2, 2004, hlm. 58 .

${ }^{38}$ H.R. Hidayat Suryalaga, Filsafat Sunda, Sekilas Interpretasi Folklor Sunda, Bandung: Yayasan Nur Hidayah, 2010, hlm. 67-70, 82-84. 
tarekat Shatariyah dan pesantren di Nusantara.

\section{Mustapa dan Tradisi Sufistik}

Latar kehidupan Mustapa tidak terlepas dari dunia pesantren dan tarekat. Sejak kecil ia dididik di pesantren yang dekat dengan jaringan tarekat di tatar Sunda. Tidak sedikit dari keluarga ibunya berasal dari ulama pesantren sekaligus penganut tarekat seperti KH. Hasan Basri (Kiarakonéng Suci, Garut) dan Kyai Muhammad (Cibunut, Karangpawitan Garut). ${ }^{39} \mathrm{KH}$. Hasan Basri (w. 1865) merupakan murid Kyai Mulabaruk dari Sukawening Garut. Ia adalah ulama ahli tafsir yang mampu menempatkan para muridnya di seluruh Priangan setelah mereka belajar dari Mekah lalu ke Madura. ${ }^{40}$ Sementara Kyai Muhammad Garut disebut-sebut sebagai salah satu mata rantai yang menghubungkan Jawa dan Mekkah. Meski menguasai bahasa Arab dan fiqih, tetapi minat utamanya adalah mistisisme (tasawuf). ${ }^{41}$

Selain Muhammad Garut, Mustapa berguru pada banyak ulama tarekat lainnya, baik Shattariyah maupun Naqsabandiyah, terutama selama ia tinggal belasan tahun di Mekah (18601862, 1869-1873, 1877-1882). Ia belajar pada Shaykh 'Abdulhamīd Daghistāni Sarawāni, Shaykh 'A Ali Rahbānī, Shaykh 'Umar Shāmī, Shaykh Muștafá 'Afifí, Sayyid Abū Bakar al-Sațā Hasbullāh, dan 'Abdullāh Al-Zawawì. Snouck

${ }^{39}$ Tini Kartini et.al., Biografi dan Karya Pujangga Haji Hasan Mustapa, Jakarta: Pusat Pembinaan dan Pengembangan Bahasa Depdikbud Jakarta, 1985, hlm. 13; Ajip Rosidi, Haji Hasan Mustapa jeung Karya-karyana, hlm. 48.

${ }^{40}$ Michael Laffan, The Makings of Indonesian Islam, hlm. 152-153 dan 275-276.

${ }^{41}$ C. Snouck Hurgronje, Mekka in the Latter Part of the 19th Century, trans. J.H. Monahan with an introduction by Jan Just Witkam. Leiden: Brill, 2007, hlm. 286-287. menyebut bahwa Mustapa juga belajar pada Nawawi Al-Bantani (1813-1897). ${ }^{42}$ Seorang ulama arsitek intelektual pesantren yang berhasil mendidik sejumlah ulama pesantren terkemuka, seperti Mahfudz Termas (1868-1919) dan Hasyim Asy'ari (1871-1947). ${ }^{43}$ Sementara nama Daghistani dan Abdullah Zawawi dikenal sebagai ulama yang berafiliasi ke dalam tarekat Naqsabandiyah. $^{44}$ Mustapa mengaku pernah diajarkan kitab Tuhfah oleh Daghistani. $^{45}$ Kemungkinan adalah Tuhfatul Muḥtāj karya Ibn Hajar alHaytami di mana Daghistani memberikan hashiyah (catatan pinggir) padanya. Sebuah kitab fiqih Shafi'iyyah yang sampai sekarang masih dijadikan rujukan di pesantren. Sementara 'Abdullah Zawawi (1266-1343 H) dikenal menjadi guru bagi banyak ulama Nusantara termasuk Hasyim Asy'ari dan Ahmad Sanusi (1888-1950). ${ }^{46}$

Sekembalinya dari tanah suci, Mustapa berteman dekat dengan C. Snouck Hurgronje (1857-1936). Kedekatan Mustapa dengannya tidak dapat diabaikan karena sangat berpengaruh terhadap perjalanan hidup Mustapa sebagai seorang elite pribumi (hoofd penghulu) di Aceh dan Bandung.

42 Michael Laffan, The Makings of Indonesian Islam, hlm. 149.

43 Abdurrahman Mas'ud, Intelektual Pesantren: Perhelatan Agama dan Tradisi, Yogyakarta: LkiS, 2004, hlm. 95-132 dan 197-221.

${ }^{44}$ Martin van Bruinessen, Tarekat Naqsabandiyah di Indonesia,Survey Historis, Geografis dan Sosiologis, Bandung: Mizan, 1992, hlm. 72-73.

${ }^{45}$ Ajip Rosidi, Haji Hasan Mustapa jeung Karyakaryana, hlm. 48.

${ }^{46}$ Mohammad Iskandar, Para Pengemban Amanah, Pergulatan Pemikiran Kiai dan Ulama di Jawa Barat, 1900-1950 (Yogyakarta: Mata Bangsa, 2001), hlm. 86. 'Umar 'Abd al-Jabbar, Siyar wa Tarajim Ba'dh 'Ulama'ina fi Al-Qarn al-Rabi' 'Asyr li al-Hijrah (Jeddah: Mamlakah al'Arabiyyah al-Su'udiyyah, 1403 H/1982 M), cet. ke-3, hlm. 140-142. 
Karyanya tentang tanya-jawab Aceh dan Pidie menunjukkan dukungannya atas kebijakan kolonial pada masanya. ${ }^{47}$ Ia merupakan salah satu informan pribumi yang memberi kemudahan bagi Snouck untuk masuk ke sisi terdalam Islam dan Muslim di Hindia Belanda. ${ }^{48}$ Mustapa adalah kelanjutan dari "Musa" lain, dan Snouck adalah "Holle" lain. ${ }^{49}$ Bagi Snouck, Mustapa menjadi salah satu tokoh kunci pengetahuan tentang Islam lokal termasuk dunia tarekat. ${ }^{50}$ Snouck sendiri akhirnya mengaku pernah dibaiat dalam tarekat. Karyanya De Atjehers (1893) seakan mengembalikan jejak silsilah tarekat Shattariyah yang ditemuinya di Jawa Barat sampai kepada 'Abdurrauf. ${ }^{51}$ Berkat kedekatannya dengan Snouck, ia juga pernah diajak ikut berkeliling Jawa dua kali dalam dua tahun (Juli 1889-Februari 1891). Ia mengunjungi banyak tempat termasuk sejumlah pesantren. ${ }^{52}$ Mustapa mengaku banyak menyalin berbagai primbon,

${ }^{47}$ Mufti Ali, “A Study of Hasan Mustafa's Fatwa: It is Incumbent upon the Indonesian Muslims to be Loyal to the Dutch East Indies Government," Journal of the Pakistan Historical Society, April 2004, Vol. 52 Issue 2, hlm. 91-122.

${ }^{48}$ Michael Francis Laffan, Islamic Nationhood and Colonial Indonesia, The Umma below the Winds (London-New York: Routledge Curzon, 2003), hlm. 82-84.

49 Tentang kedekatan R.H. Muhammad Musa (1822-1886) dan K. F. Holle (1829-1896), lihat Mikihiro Moriyama, Semangat Baru: Kolonialisme, Budaya Cetak dan Kesastraan Sunda Abad ke-19, trans. Suryadi (Jakarta: KPG, 2005).

${ }^{50}$ Lihat surat-surat Mustapa, MS. 8952 tertanggal 21 September 1907

51 Michael Laffan, The Makings of Indonesian Islam, hlm. 156. Lihat C. Snouck Hurgronje, The Achehnese, 2 Volumes, Leiden: Brill, 1906.

${ }^{52}$ PH. S. van Ronkel. "Aanteekeningen over Islam en Folklore in West-en Midden Java, Uit Het Reisjournaal van Dr. C. Snouck Hurgronje," $B K I$ 101 (1942): 311-339. Haji Hasan Mustapa, Gendingan Dangding Sunda Birahi Katut Wirahmana Djilid A (Bandung: Jajasan Kudjang, 1976), hlm. 49. kitab, pusaka dari Jawa yang kemudian diserahkan kepada Snouck yang membayarnya 150 perbulan. ${ }^{53}$ Banyak di antara yang dikumpulkannya merupakan teks Shattariyah. ${ }^{54}$ Karenanya bisa dipahami bila dalam beberapa karyanya, Mustapa seringkali menyebut-nyebut tarekat ini. $^{55}$

Kedekatan Mustapa dengan tarekat Shattariyah juga muncul dalam silsilah tarekat tersebut. Salah satunya dalam manuskrip Shattariyah di Pamijahan. Mustapa disebutkan sebagai Penghulu Bandung yang memiliki silsilah tarekat dengan Syeikh Abdul Muhyi melalui Haji Abdullah. ${ }^{56}$ Dalam versi lain, Mustapa juga disebut-sebut memiliki hubungan kerabat dengan Raden Kartinagara atau R.H. Abdullah Saleh (wafat sekitar 1911-1919) penyusun Naskah Sajarah Sukapura. Kartinagara merupakan guru tarekat keturunan kelima Syeikh Abdul Muhyi dan Bupati Sukapura, Rd. Anggadipa III atau Dalem Sawidak. ${ }^{57}$

Posisi Mustapa cenderung berbeda dengan ulama pesantren yang tetap menjadi kelompok independen dan berada di luar sistem kekuasaan

53 Haji Hasan Mustapa, Bab Adat $^{2}$ Oerang Priangan Djeung Oerang Soenda Lian ti Eta, Ditjitakna di kantor tjitak Kangdjeng Goepernemen di nagara Batawi, 1913, hlm. 194.

${ }^{54}$ Michael Laffan, "New Turn to Mecca: Snapshots of Arabic Printing and Sufi Networks in Late 19th Century Java," Revue des mondes musulmans et de la Mediterranee, 124 (2), 2008: 113-131; Edi S. Ekadjati, Naskah Sunda: Inventarisasi dan Pencatatan. Bandung: Lembaga Penelitian Unpad-The Toyota Foundation, 1988, hlm. 231-232.

55 Ajip Rosidi, Haji Hasan Mustapa jeung Karyakaryana, hlm 379 dan 428.

56 Tommy Christomy, "Shattariyah Tradition in West Java: the Case of Pamijahan," Studia Islamika, Vol. 8, No. 2, 2001, hlm. 74 dan 82; Tommy Christomy, Signs of the Wali, hlm. 105.

57 Emuch Hermansoemantri, Sajarah Sukapura, Sebuah Telaah Filologis, Disertasi Universitas Indonesia Jakarta, 1979, hlm. 93-96 dan 823. 
kolonial. $^{58}$ Namun meski demikian, sebagai ulama birokrat, Mustapa tetap memiliki hubungan baik dengan kalangan pesantren hingga akhir hayatnya. Ini terlihat dalam korespondensinya dengan Kyai Kurdi (w. 1909) dari Pesantren Sukawangi, Singaparna Tasikmalaya. ${ }^{59}$ Mustapa juga dekat dengan Ajengan Bangkonol, pengagumnya sekaligus pemilik pesantren di daerah Bandung timur. Bangkonol juga merupakan mertua $\mathrm{M}$. Wangsaatmadja, sekretaris Mustapa. ${ }^{60}$

Sampai di sini, kiranya terlihat latar dan kecenderungan Mustapa banyak dipengaruhi oleh tradisi tasawuf Nusantara terutama tarekat Shattariyah termasuk dalam mengembangkan ajaran martabat tujuh. Di tangan Mustapa, ajaran martabat tujuh kemudian menjadi landasan pemikiran di hampir semua dangding sufistiknya.

\section{Dangding Sufistik Haji Hasan Mustapa}

Dalam tradisi sastra Sunda, sastra sufistik Sunda berkembang setelah semakin menguatnya pengaruh Islam di tatar Sunda pasca jatuhnya Kerajaan Sunda pada 1579. Islamisasi melalui jalur Cirebon dan Banten yang didukung Jawa-Mataram berdampak pada masuknya pengaruh budaya Jawa terhadap tradisi sastra Sunda. Sastra Sunda tradisional berbentuk dangding atau guguritan atau juga cerita berupa wawacan semula merupakan karya sastra tulis Jawa-Mataram yang berkembang sekitar abad ke-17. Dangding bisa

58 Jajat Burhanudin, Islamic Knowledge, Authority and Political Power: The 'Ulama in Colonial Indonesia, Leiden University, 2007, hlm. 117.

59 Haji Hasan Mustapa, Balé Bandung. Bandung: Rahmat Cijulang, 1984.

${ }^{60}$ Ajip Rosidi, Haji Hasan Mustapa jeung Karyakaryana, hlm. 8-9; Ajip Rosidi, Hurip Waras, Dua Panineungan, Bandung: Kiblat Buku Utama, 2001, cet. ke-2, hlm. 118. dianggap menjadi ciri keterpelajaran orang Sunda dalam menyerap pengaruh budaya Jawa. Dangding merupakan karya sastera tulis yang berisi berbagai hal, termasuk cerita (hikayat, roman) atau uraian agama yang ditulis berbentuk puisi dengan pola 17 jenis pupuh. $^{61}$ Seperti halnya macapat di Jawa, dangding dan wawacan biasa ditembangkan atau disenandungkan. ${ }^{62}$

Secara umum, sastra Sunda tradisional seperti dangding banyak dikembangkan oleh kalangan ménak Sunda. Dari R.H. Muhammad Musa (1822-1886), R.A.A. Kusumaningrat alias Dalem Pancaniti, Bupati Cianjur (1834-1863), R.A.A. Martanagara, Bupati Bandung (1893-1918), hingga R.A.A. Wiranatakusumah (18881965). ${ }^{63}$ Namun dari sekian banyak menak Sunda tersebut, kiranya Mustapa yang lebih kental dengan tradisi sastra sufistik Sunda. Konsernnya pada mistisisme Sunda memang mencengangkan bila melihat rentang waktu disusunnya dangding mistik tersebut (1900-1902). ${ }^{64}$ Di banding karya prosanya, dangding Mustapa masih banyak yang belum tersentuh. Dari sekitar 10.000 bait dengan lebih dari 70 judul dangding, belum seluruhnya ditransliterasi dan dipublikasikan. Sebagian naskahnya masih tersimpan di UB Leiden. ${ }^{65}$ Selain koleksi UB Leiden, naskah salinan karya dangding Mustapa juga terdapat di

61 Ma'mur Danasasmita, Wacana Bahasa dan Sastra Sunda Lama (Bandung: STSI Press, 2001), hlm. 171-172.

62 Ajip Rosidi, Mencari Sosok Manusia Sunda (Bandung: Pustaka Jaya, 2010), hlm. 30-31 dan 194.

63 Nina H. Lubis, Kehidupan Menak Priangan 1800-1942 (Bandung: Pusat Informasi Kebudayaan Sunda, 1998), hlm. 240-241.

64 Ajip Rosidi ed., Ensiklopedi Sunda, Alam, Budaya, dan Manusia (Jakarta: Pustaka Jaya, 2003), hlm. 263.

${ }^{65}$ Edi S. Ekadjati, Naskah Sunda, hlm. 213. 
Perpusnas Jakarta dan koleksi individu. Salah satunya adalah hasil salinan $\mathrm{M}$. Wangsaatmadja, sekretaris Mustapa. Hasil suntingannya itu diberi judul $A j i$ Wiwitan I-IV. Sayangnya Wangsaatmadja menyalinnya ke dalam aksara Roman dan kemudian naskah asli tulisan tangan Mustapa dimusnahkannya. ${ }^{66}$ Salah satu dangding Mustapa hasil salinan Wangsaatmadja terdapat dalam karya prosa Adji Wiwitan Martabat Tujuh. Karya ini umumnya berisi komentar-komentar singkat yang menggambarkan ajaran martabat tujuh yang tidak beranjak dari tema besar tasawuf Nusantara. Namun di dalamnya ternyata juga terdapat empat judul puisi dangding Kinanti, yakni Kinanti Disusul Teu Manggih Tungtung (20 bait); Dumuk Batur Dumuk Gunung (Kinanti Munggah Haji) (14?); Nya Nyingkur Wujud ku Batur (3); dan Asal ge Balung Sabalung (8). ${ }^{67}$

Secara struktur, rancang bangun dangding Mustapa memiliki kekhasan terutama pada diksi yang yang seringkali tidak terduga, permainan mengolah bunyi kata yang bersuara nyaris sama, dan struktur bait-baitnya yang kerapkali menggunakan sampiran sebagai pembuka layaknya rajah dalam pantun Sunda. ${ }^{68}$ Dangding Mustapa juga sebenarnya bukan sekedar konstruksi verbal tetapi juga konstruksi tembang musikal. Terjadi persenyawaan antara ekspresi spiritual dengan cita rasa seni manakala dangding dialunkan. Biasanya dengan iringan kecapi atau instrumen musik lainnya, citra dan simbolisme lokal yang bersumber dari kekayaan

${ }^{66}$ Tini Kartini et.al., Biografi dan Karya Pujangga Haji Hasan Mustapa, hlm. 39.

${ }^{67}$ Haji Hasan Mustapa, Adji Wiwitan Martabat Tudjuh, hlm. 21-22; 37-38; 57; dan 66.

${ }^{68}$ Hawe Setiawan, "Dangding Mistis Haji Hasan Mustapa," Makalah Seri Kuliah Umum Islam dan Mistisime Nusantara di Teater Salihara, 4 Agustus 2012, hlm. 10. batin orang Sunda begitu mudahnya keluar secara spontan. Mustapa kerap menggunakan banyak metafor alam kesundaan dalam dangding-nya. Ia menggambarkan hubungan khalikmakhluk dalam proses pencarian diri yang dijejakkan dalam bingkai tradisi sufistik. ${ }^{69}$ Metafor alam kesundaan juga tampak terlihat dalam penafsirannya atas ajaran martabat tujuh sebagai poros inti dari dangding-nya.

\section{Martabat Tujuh dalam Dangding}

Dalam salah satu dangding-nya, Pucung Lutung buntung naek kana pager gintung (Pucung, Monyet buntung naik ke atas pagar gintung), Mustapa menggambarkan apa yang dimaksudkannya dengan martabat (alam) tujuh.

\section{Alam tudjuh nu tilu bagian itu Ahadiat wahdat wahidiat kabéh Lamun nelah di aing ngan bobodoan}

Alam tujuh itu tiga bagian

Ahadiat, wahdat, wahidiat, semua

Bila disebut ada padaku sekedar bohongan

\section{Anu opat bagian aja di mahluk} Njawa misal djasmani insanan kabéh Lebah dieu lahir njembah kabatinan ${ }^{70}$

Yang empat bagian ada di makhluk Nyawa (arwah), mitsal, jasmani (ajsam), insan (kamil), semua

Di sini lahir menyembah batin

${ }^{69}$ Jajang A Rohmana, 'Sundanese Sufi Literature and Local Islamic Identity: A Contribution of Haji Hasan Mustapa's Dangding.' Journal AlJamiah, Vol. 50, No. 2, hlm. 317.

70 Haji Hasan Mustapa, Gendingan Dangding Sunda Birahi Katut Wirahmana Djilid A, hlm. 183. 
Mustapa sebagaimana AlBurhanfuri dan juga Abdul Muhyi, menyebut bahwa martabat tujuh terdiri dari ahadiyat, wahdat, wahidiyat, alam arwah (nyawa), alam mitsal, alam ajsam (jasmani), dan insan kamil (insanan). Tiga martabat pertama ada pada Tuhan, empat sisanya di makhluk. Ketiga wujud pertama Tuhan itu bersifat qadim (tak diciptakan, terdahulu), sementara keadaan hamba Allah adalah muhdats (diciptakan, baru). ${ }^{71}$ Basis ajaran martabat tujuh bermula dari asumsi bahwa Tuhan adalah Wujud Mutlak. Ia lalu mewujud ke alam nyata melalui tujuh tingkatan 'emanasi' atau tajalli. Tingkatan ahadiyah, wahdat, wahidiyat merupakan tiga alam tanpa wujud luar, sedang empat sisanya (arwah, mitsal, ajsam, insan kamil) sebagai wujud luar. ${ }^{72}$ Karenanya, bagi Mustapa tiga martabat pertama tidak bisa benar-benar ada pada diri manusia secara lahir. "Bohong saja bila diri lahirnya mengaku mendapatkan ketiga alam ketuhanan tersebut," demikian katanya. Karena ketiganya pada dasarnya bersifat batin. Begitu pun keempat alam sisanya hanya terdapat di alam makhluk, yakni alam lahir. Sebuah alam yang tidak bisa terlepas dari alam batin ketuhanan sebagai sumbernya.

Gambaran Mustapa tentang martabat alam tujuh tersebut tidak diragukan lagi mencerminkan pengaruh ajaran metafisika wujud yang bersumber dari Al-Burhanfuri. Dalam karya singkatnya, Tuhfah al-Mursalah ilā Rūh al-Nabì, Al-Burhanfuri menjelaskan apa yang dimaksudkannya dengan tujuh martabat wujud tersebut:

71 Aliefya M. Santrie, "Martabat Alam Tujuh, Suatu Naskah Mistik Islam dari Desa Karang Pamijahan," dalam Ahmad Rifa'i Hasan, ed., Warisan Intelektual Islam Indonesia (Bandung: Mizan, 1992), cet. ke-3, hlm. 114.

72 A.H. Johns, The Gift Adressed to the Spirit of the Prophet, hlm. 7.

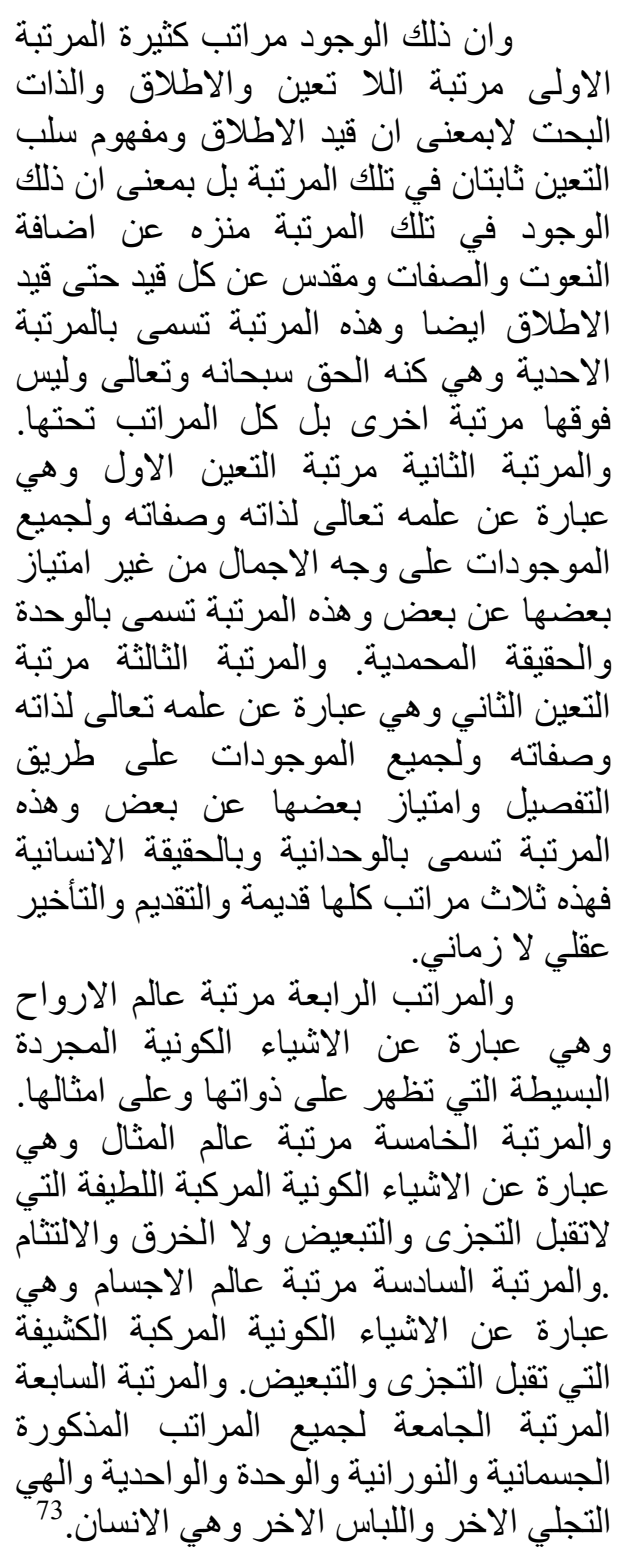

Al-Burhanfuri tampak berusaha menjembatani metafisika alam wujud ke arah ajaran wahdatul wujud yang lebih ortodoks. Tak ada kecenderungan panteisme heterodoks di sini. Ia berada pada jalur ortodoksi wahdatul wujud di tengah heterodoksi tafsir atas ajaran wahdatul wujud Ibn 'Arabi dan Al-Jili. Ia memberikan tafsir ortodoks atas gradasi wujud Ibn 'Arabi terutama dalam Fușuṣ al-Hikam dan Futūhăt alMakkiyah serta Al-Jili dalam Al-Insān al-Kāmil fì Ma'rifat al-Awā'il wa al73 A.H. Johns, The Gift Adressed to the Spirit of
the Prophet, hlm. 130-131. 
Awākhir. ${ }^{74}$ Ibn 'Arabi dikenal sebagai perintis ajaran wahdatul wujud yang menuangkan teori tajalli-nya ke dalam tiga martabat: ahadiyat, wahidiyat dan tajalli syuhudi. Sedang Al-Jili menuangkannya ke dalam lima martabat: uluhiyah, ahadiyah, wahidiyah, rahmaniyah dan rububiyah. ${ }^{75}$ Ia menegaskan keesaan mutlak Tuhan yang tidak mengalami perubahan dan berbeda dengan makhluk. Makhluk diciptakan melalui tajalli-Nya dalam tujuh martabat wujud. Semuanya berkumpul dalam wujud alam insan kamil. Nabi Muhammad kiranya merupakan puncak dari personifikasi insan kamil.

Mustapa sebagai mistikus Sunda kemudian menggunakan ajaran ini sebagai pijakan dalam meningkatan martabat rohani. Ia merinci apa yang dimaksudnya dengan martabat alam tujuh tersebut sebagai martabat rohani sufistik. Ia menjelaskan secara singkat apa saja yang dirasakan saat berada dalam situasi setiap martabat dengan menyebutnya sebagai lautan martabat:

Lautan Ahadiyat mirasa katunggalan, di bukurna lautan Ajsam, mirasa jisim sahiji; Lautan Wahdat, mirasa pada mirasa, balukarna ngambang rasa, milang dua jadi hiji, jisim dua jadi hiji,

Lautan Wahidiyat, mirasa loba bilangan, kapirasa jadi hiji, balukarna milang nyawa, loba-loba rasa hiji;

Lautan Arwah-na, jisim loba-loba rasa hiji, dibukuran ku jisimna, loba-loba rasa hiji;

Lautan Misal, loba jisim hiji rupa, asalna alam sahiji;

\footnotetext{
${ }^{74}$ Lihat Ibn 'Arabi, Futūhàt al-Makkiyyah, Tahqiq Uthman Yahya, Kairo: Al-Hay'at al-Misriyyah al-'Ammah li al-Kitab, 1972; 'Abdul Karim AlJili, Al-Insān al-Kāmil fí Ma'rifat al-Awā'il wa al-Awākhir, Beirut: Dar al-Fikr, t.th.

75 Ahmad Daudy, Allah dan Manusia dalam Konsepsi Syeikh Nuruddin Ar-Raniry, Jakarta: Rajawali Press, 1983, hlm. 74-75; Yunasril Ali, Manusia Citra Ilahi, hlm. 129.
}

Lautan Ajsam, kapirasa jadi hiji, perbawa ti Ahadiyat, lima laut dumukna di jisim hiji;

Lautan Kainsanan, taya luhur taya handap, asal sampurna walatra, béda soteh pangersa panarimana. ${ }^{76}$

Mustapa memberikan tafsir martabat tujuh dari metafisika wujud ke arah martabat rohani. Alam Ahadiyat dipahaminya sebagai rasa ketunggalan (Tuhan dan makhluk) secara batin dalam wujud jasad individual. Alam Wahdat berada pada tahap saling merasa dan mengambang, masih berhitung adanya dua esensi yang menjadi satu. Alam Wahidiyat merasa banyak bilangan, terasa menjadi satu setelah menghitung arwah. Banyak ruh tetapi rasa satu. Alam Arwah berarti banyak jasad tetapi rasa satu, materialnya jasad yang banyak tetapi rasa satu. Alam Mitsal berarti banyak jasad tetapi serupa karena alamnya satu. Alam Ajsam berarti rasa satu bawaan dari Ahadiyat, lima lautan wujud sebelumnya tinggal di jasad satu. Semua berujung pada Alam Insan kamil yang berarti tiada atas, tiada bawah, sumber/asal semua jelas sempurna, perbedaan karena kehendak yang menerimanya.

Masih dalam karya prosanya, $A j i$ Wiwitan Martabat Tujuh, Mustapa merinci apa yang dimaksud ketujuh martabat itu. Ia menarik ajaran tersebut dari metafisika ketuhanan yang tanazzul (menurun) dari Tuhan ke makhluk menjadi suatu kondisi ketika sufi mencari kesejatian diri secara taraqqi (naik). Ini bisa dibandingkan dengan Gelaran Sasaka di Kaislaman yang cenderung mengembangkan fase-fase rohani (maqamat) yang berasal dari alJili. Mustapa menyebut fase "Islamiman-soleh-ihsan-sahadah-sidikiyah-

\footnotetext{
76 Ajip Rosidi, Haji Hasan Mustapa jeung Karyakaryana, hlm. 308.
} 
kurbah."77 Ia sebenarnya merupakan lanjutan dari martabat tujuh. Bila martabat tujuh merupakan tajalli Tuhan secara tanazzul (turun) ke arah insan kamil sebagai citra Tuhan, maka maqamat dalam Gelaran merupakan perjalanan manusia secara taraqqi (naik) ke arah pembentukan insan kamil. $^{78}$ Mustapa tampak berusaha memainkan martabat tujuh secara turun-naik layaknya sebuah 'siklus spiritual.' Sebuah perjalanan dirinya sebagai makhluk yang berusaha kembali ke kesejatian asal diri dalam mewujudkan citra Tuhan di bumi.

Ahadiat patunggalan, asal suwung bakal suwung, la ta'yun, taya bukur anu ti naktu gaib, ditapaan hayang tepi ka nyatana, pakeun ari kasengkek, nu baris nulungan ku élmu nur suhud, balukarna hayang murbawisesa, taya kaseubeuhanana;

Wahdat patunggalan abdi lawan gusti, abdi-abdi nya manéhna kénéh, gusti-gusti nya ahadiyat, nu gaib rék dipuntangan, manéhna henteu bijil ti kaabdian saha anu kasukman purbaning gusti, karasa $\mathrm{ku}$ pitulungna,

Wahidiyat patunggalan $\mathrm{ka}$ ajsam batur abdi aing abdi, hakékat Muhammadiyah, saha anu katiban sukma, nya éta anu pangunggulna, anu matak manusa martabat tujuh Wahdatullah, Wahadiyat Muhammad, Wahdat piabdieun, ngaula $\mathrm{ka}$ wahdatul Allah;

Arwah patunggalan, dunya nyawa kaulaaneun $\mathrm{ku}$ jasad, unggal anu sampurna samahina ka nu di dunya, balukarna pupuja ka nu sampurna, ngabantu di kawahdiyatan, sugan nyukma sampurna ngawaris kajatnikaan,

Misal patunggalan nu unggul jadi gustina, unggal jisim anu badag nyembah kana misal, balukarna taya kaseubeuhanana, pupurba asa ngawula ku pangrasa, ana piur jadi nafsu, teu ngukur tangtung sorangan;

77 Haji Hasan Mustapa, Aji Wiwitan Gelaran Sasaka di Kaislaman, Kenging ngumpulkeun sarta ngatur Wangsaatmadja sareng para panitiana, n.p. n.d.; "Syair Mistis Bagawan Sirna Dirasa," Tempo, 16 September 2012, hlm. 68.

${ }^{78}$ Y unasril Ali, Manusia Citra Ilahi, hlm. 144-145.
Insan Kamil sampurna taya kakurang, lantaran ngala sorangan $\mathrm{ku}$ pitulung Ahadiyat, jatnika ku sangsarana. ${ }^{7}$

Pengaruh Al-Burhanfuri dan ulama Nusantara seperti Al-Raniri, Abdurrauf Al-Jawi al-Sinkili dan Abdul Muhyi tampak jelas pada interpretasi Mustapa tersebut. Mustapa menegaskan apa yang dimaksud ketujuh martabat itu. Ia kembali menarik siklus ajaran tersebut dari metafisika ketuhanan yang tanazzul dari Tuhan ke makhluk menjadi suatu kondisi ketika sufi mencari kesejatian diri secara taraqqi dan mengalami 'penyatuan' batin dengan Tuhan.

Mustapa sebagaimana AlBurhanfuri cenderung memahami metafisika wujud tersebut secara ortodoks yang ditarik ke arah pencarian diri. Baginya, martabat tujuh bermakna pencarian spiritualitas batin dalam bingkai bahasa metafor dan simbol. Tidak ada makna panteisme heterodoks sebagaimana disangkakan banyak orang terhadapnya. Sebuah ajaran tasawuf yang meyakini bahwa hanya ada satu wujud semata, yakni Wujud Allah, sedang selain-Nya hanyalah ilusi. ${ }^{80}$ Mustapa tidak meyakini bahwa realitas ini tiada, tidak juga abadi dan berada pada Tuhan, tetapi menganggap bahwa ia tidak bisa dipisahkan dari Tuhan dan sangat bergantung pada-Nya. Karenanya, kita tidak sepenuhnya bisa mengatakan bahwa Mustapa meyakini ajaran wahdat al-wujûd secara ekstrem.

Ia bahkan berani membantah kesalahfahaman orang dalam karyanya Injāz al-Wa'd fí Itfá' al-Ra'd (Or. 7205) terkait 'surat kaleng' yang ditujukan kepada dirinya diduga dikirimkan oleh

\footnotetext{
79 Ajip Rosidi, Haji Hasan Mustapa jeung Karyakaryana, hlm. 309.

80 Abu Al-Wafa' Al-Ghanimi Al-Taftazani, Sufi dari Zaman ke Zaman, terj. Ahmad Rofi' 'Utsmani, (Bandung: Pustaka, 1987), hlm. 200.
} 
Sayyid Uthman sekitar $1902 .{ }^{81}$ Ia dituduh menyimpang dari ajaran Islam karena cenderung mengabaikan syariat. Sebuah isu yang tidak tepat dilihat dari arus besar pemikiran mistiknya yang cenderung rekonsiliatif. Dalam dangding Sinom Piwulang Si Runcangkundang, Mustapa menceritakan pengalaman tersebut. Ia membantah tuduhan kafir dan zindik dengan menegaskan sikapnya sebagai orang yang beuki ti barang eling terhadap syariat (salat dan puasa):

Bédja madjarkeun kaula geus leungit elmuning santri geus ngaruksakkeun agama djadi kapir djadi djindik djindikna djadi mungkir kana tutur lampah rasul kana salat puasa ana malik kula njeri kahuruan ngadjawab djeung handaruan

Isu bahwa Aku sudah hilang ilmu santri sudah merusak agama jadi kafir jadi zindik zindiknya menjadi mungkir pada sabda dan amalan rasul pada salat puasa sebaliknya Aku merasa sakit hati bernafsu menjawab penuh semangat

Handaruan djeung susumbar aeh naha kitu teuing kitu kutan kitu kutan nu palid tinggaleun palid palidna nja pribadi geus ngalun ka alun-alun alunan nu sampurna malik ka bagdjaning diri aduh biang kasampurnaning sambéang

Semangat disertai sesumbar mengapa kok begitu

${ }^{81}$ Ajip Rosidi, Haji Hasan Mustapa jeung Karyakaryana, hlm. 434 dan 494. ternyata begini begitu yang hanyut tinggal hanyut hanyutnya pribadi mengambang ke alun-alun ambangan yang sempurna kembali ke kebahagiaan diri aduh biung kesempurnaan sembahyang

\section{Sambéang mustika urang kabeuki ti barang éling baheula djadi kalangkang geusan mihajang miéling éling2 geus éling singhoréng tungguling tangtung tangtung geusan rumingkang djadi kabeuki aing aing sirna bagdja teu tjara saria. ${ }^{82}$}

Sembahyang perhiasan kita Hobi sejak mulai eling Dulu menjadi bayangan Agar berkeinginan, agar eling Eling-eling sudah eling Ternyata tunggulan eksistensi Eksistensi tempat hidup Menjadi kesukaanku Aku sirna bahagia tidak dengan cara yang sama

Sebagaimana sufi Sunni lainnya, tasawuf Mustapa kiranya menekankan pada tasawuf rekonsiliatif yang menekankan misteri ketersembunyian Tuhan yang hanya bisa diketahui melalui ciptaan-Nya. Ini misalnya terjadi juga pada tasawuf Hamzah Fansuri. ${ }^{83}$ Karenanya dalam banyak dangding-nya Mustapa menggunakan ragam simbol

82 Haji Hasan Mustapa, Dangding Djilid Anu Kaopat, stensilan kenging ngusahakeun Ajip Rosidi, Tjihideung, Oktober 1960, hlm. 53.

83 Syed Muhammad Naguib Al-Attas, The Mysticism of Hamzah Fansuri. Kuala Lumpur: University of Malaya Press, 1970; Karel Steenbrink, "Qur'an Interpretations of Hamzah Fansuri (CA. 1600) and Hamka (1908-1982): A Comparison," Studia Islamika, Vol. 2, No. 2, 1995, hlm. 84. 
dan metafor yang tetap membedakan antara dirinya dengan Tuhan meski tidak terpisahkan. Ia membedakan antara aren dengan caruluk, iwung dan bambu, bambu-haur, bambu-angklung, duwegankitri, beras-padi, sirung-benih, tongtolang dengan nangka, hayam dan endog (ayam dan telur) dan yang lainnya. ${ }^{84}$ Pembedaan khalik-makhluk menjadi ciri dari upaya tafsir ulama Nusantara atas ajaran wahdat al-wujud. Umumnya ulama sufi Nusantara cenderung mengajukan upaya rekonsiliasi tasawuf (neo-sufisme). Mustapa kiranya juga sangat dipengaruhi tema besar tasawuf abad ke17 dan 18 ini.

Dalam salah satu puisinya yang paling populer, Mustapa memainkan siklus turun-naik dari gradasi wujud ke martabat rohani tersebut dengan menggunakan metafor tangtung-aing, saha-aing, beja-yakin, kidul-kaler, kulonwetan, maneh-aing, atau aya-euweuh. Ini misalnya tampak dalam puisi Kinanti Puyuh Ngungkung dina Kurung.

Ngalantung néangan tangtung

Aing deui aing deui

Sapanjang néangan saha

Aing deui aing deui

Sapanjang néangan beja

Yakin deui yakin deui

Mencari-cari pijakan eksistensi

hanya Aku kujumpa

Sepanjang mencari siapa

hanya Aku kujumpa

Sepanjang mencari berita

hanya yakin kujumpa

\footnotetext{
${ }^{84}$ Jajang A Rohmana, "Makhtutat Kinanti [Tutur teu Kacatur Batur]: Tasawwuf al-'Alam alSundawi 'ind al-Hajj Hasan Mustafa (18521930)," Studia Islamika, Vol. 20, No. 2, 2013: 325-375.
}

\section{Sapanjang néangan kidul kalér deui kalér deui sapanjang néangan wétan kulon deui kulon deui sapanjang néangan aya euweuh deui euweuh deui ${ }^{85}$}

Sepanjang mencari selatan hanya utara kujumpa sepanjang mencari timur hanya barat kujumpa sepanjang mencari ada hanya tiada kujumpa ${ }^{86}$

Mustapa kiranya membedakan diri dan Tuhan dalam konteks wahdat alwujûd, yakni sebagai gambaran pertemuan aspek manusia (nasût) dan aspek ketuhanan (lahût) dalam dirinya. Jarak keduanya dianggap tak terbatas. Suluk merupakan sebuah perjalanan dari nasût ke lahût. Ia menggambarkan percariannya dari nasut ke lahut, dari eksistensi ke Aku, dari siapa ke Aku, dari selatan ke utara, dari timur ke barat, dan dari ada ke tiada. Proses kembali diri ke tempat beranjaknya semula. Ia merasakan sudah sampai pada tempat itu. Ia ibarat siklus, dari Ahadiyat ke insan kamil, dari insan kamil ke ahadiyat.

Dirinya (yang terselang) menjadi manusia disadari berasal dari Tuhan dan harus kembali ke Tuhan. Ia harus mengalami penyatuan eksistensi kembali (wahdat al-wujûd) sehingga mampu memancarkan mutiara eksistensi-Nya yang tersembunyi di dunia (kanzan makhfiyyan), menunjukkan kebesaranNya, dan mengemban sifat-sifat Ilahi. Kehendaknya harus menyatu dengan kehendak Tuhan. Inilah pencarian lahût

\footnotetext{
${ }^{85}$ Haji Hasan Mustapa, Gendingan Dangding, hlm. 140; Ajip Rosidi, Haji Hasan Mustapa jeung Karya-karyana, hlm. 96-97.

${ }^{86}$ Terjemah bait terakhir dipinjam dari Teddy AN Muhtadin.
} 
dalam nasût. Layaknya logika paradoksal antara bentuk (form) dan isi (essence). Pada aspek ketuhanan terdapat aspek manusia, dan demikian pula sebaliknya. ${ }^{87}$

Baginya ketika ekstase terjadi tidak pernah sampai kehilangan aspek manusia atau pun kehilangan aspek ketuhanan. Tidak ada yang lenyap, masih manusia dan masih Tuhan. Penyatuan eksistensial inilah yang seringkali disalahpahami oleh para ulama zahir) dengan menuding secara panteistik bahwa ia betul-betul melebur dan lenyap. Dalam dangding ini, ia menggambarkannya dengan perasaan hilangnya objek, yang ditemukan hanya aku sang ego (aing) yang sudah tiada lagi jarak, bukan lagi hamba ( ' $a b d$ ).

Karenanya kiranya tepat bila Johns mengatakan bahwa ortodoksi ajaran martabat tujuh terletak pada beberapa poin penting: 1) Tuhan merupakan sumber segala sesuatu; 2) Tiada apapun selain Tuhan yang bereksistensi dengan kehendaknya sendiri; 3) Setiap sesuatu yang berbeda satu sama lain (mufassal) adalah tidak sama dengan Tuhan, meskipun sebelum penciptaan semuanya adalah satu di dalam Diri-Nya. Penting dicatat di sini, bahwa melalui martabat tujuh tidak ada penyimpangan dalam doktrin wahdatul wujud. Ia menjadi elemen utama dalam pemikiran sufi dan menolak seluruh antinomian dan kecenderungan ekstremis. ${ }^{88}$

\section{Nepi kana urut indit (Sampai ke tempat beranjak semula)}

Sebagaimana dijelaskan di atas, dalam karya prosanya Aji Wiwitan Martabat Tujuh, Mustapa

${ }^{87}$ Jajang Jahroni, "The Life and Mystical Thought of Haji Hasan Mustafa (1852-1930)," hlm. 6263.

${ }^{88}$ A.H. Johns, The Gift Adressed to the Spirit of the Prophet, hlm. 7. mengungkapkan kesadaran dirinya akan sumber metafisika ketuhanan (wahdatul wujud/tawhid al-wujud) yang menjadi titik pijak pencarian kesejatian diri. Mustapa sebagaimana Ibn 'Arabi, AlJili, Al-Burhanfuri dan umumnya ulama Nusantara abad ke-17, cenderung menginterpretasikan ajaran martabat tujuh bukan semata-mata sebagai sintesis tajalli Ilahi, tetapi juga merupakan hasil upaya manusia dalam meningkatkan martabat rohani menuju hakikat spiritual alam sejati (fanā fí alhaqq). ${ }^{89}$ Mustapa menggambarkan pencarian itu dengan ungkapan dan metafor yang luar biasa kaya akan imajinasi alam dan budaya Sunda. Ia menggambarkan pencarian hakikat itu dari eksistensi ke Aku, dari selatan ke utara, dari timur ke barat, dari ada ke tiada. Ia juga membuat metafor pencarian itu dari ayam ke telur, dari bambu ke angklung, dari caruluk ke aren dan banyak lainnya.

Upaya pencarian tersebut menurut Al-Jili merupakan proses kembali ke hadirat Ilahi dengan menyusuri tajallitajalli hingga sampai pada Yang Mutlak. $^{90}$ Al-Kurani dalam Ithăf alDhaki mengutip Al-Qushairi, menjelaskannya sebagai penyingkapan dalam situasi ketika seorang hamba lenyap di hadapan Allah melalui fanā', dari dirinya sendiri, hilang perasaan dan gerakannya, akibat dominasi al-Haq Swt. atas dirinya dengan kehendak-Nya, dan ini adalah keadaan di mana penghujung hamba kembali ke permulaannya, sehingga dia berada dalam keadaan seperti sebelumnya. ${ }^{91}$ Ia merasakan kembali eksistensi diri yang terus naik ke puncak awal kejadian

\footnotetext{
89 Reynold A. Nicholson, The Mystics of Islam, (Indiana: World Wisdom, 2002), hlm. 21.

${ }^{90}$ Yunasril Ali, Manusia Citra Ilahi, hlm. 143.

${ }^{91}$ Oman Fathurahman, Ithaf Al-Dhaki, hlm. 118119.
} 
sebagai tujuan akhir pencarian kesejatian (insan kamil).

Insan kamil merupakan tingkatan terakhir dari martabat tersebut. Ia mencerminkan rahasia terdalam Tuhan (al-insān sirrî́). ${ }^{92}$ Gradasi metafisika wujud mencerminkan cara Tuhan menunjukkan rahasia cinta-Nya dan eksistensi-Nya. Ia menjadi perwujudan harta karun tersembunyi Tuhan agar Ia dikenal dan diketahui (kuntu kanzan makhfiyyan fakhalaqtu al-khalq fa'arrafünīi). Tuhan yang tersembunyi dalam gedong samar dalam bahasa Mustapa, lalu mengenalkan diri-Nya melalui penciptaan makhluk melalui gradasi wujud martabat tujuh. ${ }^{93}$

Karenanya, manusia insan kamil bisa mencapai kesempurnaan ketika melalui pengetahuan atas dirinya bisa mencapai pengetahuan Ketuhanan dan memahami dari mana ia berasal dan hendak ke mana ia kembali (man 'arafa nafsah faqad 'arafa rabbah). Ia adalah mikrokosmos dan berisikan lima tingkatan di atasnya. Ia adalah titik kembali di mana pemikiran tentang Tuhan yang sudah melewati berbagai tingkatan ini menuju wujud material, kembali pada kemutlakan diri-Nya. ${ }^{94}$

Mustapa mengungkapkan proses kembali itu dalam sebuah dangding pendek berjudul Kinanti Martabat Tujuh Hakekat Muhammadiyah sebagai senandung tembang spiritual. Sebuah puisi yang mengekspresikan perasaan terdalam seputar pengalaman batin

${ }^{92}$ Tentang al-insān sirrī/Asmarandana Gilisir Jadi Kinanti, lihat dangding Mustapa lainnya dengan judul Al-Insānu Sirri, dimuat dalam Haji Hasan Mustapa, Gendingan Dangding Sunda Birahi katut Wirahmana, hlm. 90-100. Tema ini dibicarakan pula dalam Kinanti Tutur teu Kacatur Batur, MS. Or. 7875.

${ }^{93}$ Haji Hasan Mustapa, Adji Wiwitan Martabat Tudjuh, hlm. 2.

${ }^{94}$ A.H. Johns, The Gift Adressed to the Spirit of the Prophet, hlm. 7. sufistik dengan berpijak pada ajaran martabat tujuh.

\section{Asal gé balung sabalung,} asal gé daging sadaging, asal sungsuam sungsuam, asal gé getih sagetih, kuma kasonoanana, ka nu hiji ti sasari.

Asal juga setulang, asal juga sedaging, asal juga sesumsum, asal juga sedarah, tergant ung kesukaannya, pada yang tunggal seperti biasa.

2. Asal gé hayun sahayun, asal gé hurip sahurip, asal gé hayat sahayat, asal gé jati sajati, kuma kasonoanana, asal lautan sahiji. ${ }^{95}$

Asal juga hayun (hidup) sehayun, asal juga hidup sehidup bahagia, asal juga hayat sehayat, asal juga jati sejati, tergantung kesukaannya, asal satu lautan.

Mustapa mencoba mengungkapkan perasaan dirinya yang kembali ke dalam sebuah situasi batin ketuhanan yang berpuncak pada asal kesejatiannya di alam batin ketuhanan. Mustapa menggunakan metafor tubuh (balung, daging, sungsuam, getih) untuk memulangkan kesadarannya. Ia menyadari bahwa dirinya semula berasal dari Yang Mutlak, setulang, sedaging, sesumsum, dan sedarah. Sebuah metafor kesatuan mutlak yang tiada terbagi. Ia

\footnotetext{
${ }^{95}$ Haji Hasan Mustapa, Adji Wiwitan Martabat Tudjuh, hlm. 66-67. Ajip Rosidi, Haji Hasan Mustapa jeung Karya-karyana, hlm. 307-308.
} 
merasa lenyap (fana') dalam dominasi Tuhan. Ia menyebut keadaan ini dengan sehidup (hayun, hurip, hayat) yang menegaskan keadaannya semula yang senafas dan sejiwa dengan Yang Mutlak. Ia menutupnya dengan metafor asal lautan sahiji. Sebuah ungkapan kesadaran tentang asal muasal diri yang bersumber dari Yang Tunggal.

Perasaan 'kembali kepada asal kesejatian diri' di alam ahadiyat tersebut kiranya menjadi kata kunci dari banyak dangding dan prosanya. Millie menyebutnya "arriving at the point of departing." 96 Ia di banyak tempat dalam karyanya ia mengungkapkannya:

\section{Kalinglung lamun kalarung \\ tinggaleun dituang bumi \\ beuki anggang beuki beurang \\ beuki leungit beuki leungit \\ mun kurang amit mundurna \\ nepi kana urut indit ${ }^{97}$}

Bingung bila tersesat

Tertinggal dimakan tanah

makin berjarak makin siang

makin hilang makin hilang

kalau kurang pamitannya

sampai pada tempat kembali

Ari ieu kiblat nu dibalikkeun supaya kanyahoan nu araranut ka Rasulullah, malik ati $\mathrm{ka}$ wiwitan jeung kasebut malik kana urut indit. Jadi basa: Ti dinya nya bijil ka dinya surupna. ${ }^{98}$

96 Julian Millie, "Arriving at the Point of Departing," hlm. 110-111.

97 Haji Hasan Mustapa, "Kinanti Kidung pucuk mega mendung" (Or. 7878) dalam Iskandarwassid, dkk. hlm. 387.

98 Haji Hasan Mustapa, Qur'anul Adhimi Adji Wiwitan Qur'an Sutji, kenging ngumpulkeun Wangsaatmadja, Bandung 7 Juli 1920, hlm. 9-10; Ajip Rosidi, Haji Hasan Mustapa jeung Karyakaryana, hlm, 398-399. Artinya: Adapun kiblat yang dirobah itu supaya diketahui siapa yang turut pada Rasulullah. Berbalik hati ke asalnya lagi dan dianggap berbalik ke tempat bekas
Bagi Mustapa, makna "nepi/balik kana urut indit" merupakan siklus puncak pencapaian kesadaran manusia akan hakikat kesejatian diri. Sebuah perasaan batin manusia insan kamil saat berada kembali ke alam ahadiyat. Bahkan ketika menafsir ayat tentang peralihan kiblat shalat (QS. Al-Baqarah [2]: 142-145), Mustapa menjelaskannya sebagai simbol kembalinya spiritualitas kenabian Muhammad menuju ke kesejatian diri. Secara historis, ayat tersebut diturunkan ketika Nabi berusia lebih dari empat puluh, sebuah usia yang mencerminkan kematangan spiritualitas. Sebuah cermin saat di mana seseorang menyadari tempat ia semula berasal.

Dalam naskah Sinom Cat Mancat ka Bale Pulang (Or. 7876), Mustapa lebih jauh menggambarkan keadaan setelah "balik kana urut indit" menuju fase kedelapan sesudah martabat tujuh. Ia menyebutnya geus ripuh di alam tujuh, kadalapan ngalayang di pamulangan.

\section{Pakandangan sasampalan}

munding mareuting di munding sirna pangawulan rasa rasaning pirbadi aing aing kari nunggeling geus ripuh di alam tujuh kadalapan ayeuna indit mawa geusan balik kadalapan ngalayang di pamulangan

Tempat kembali di padang rumput kerbau bermalam di kerbau sirna yang dilayani rasa (fana') perasaan aku pribadi aku tinggal menyendiri sudah lelah di alam (martabat) tujuh sekarang alam kedelapan

pemberangkatan awalnya. Jadi sesuai dengan peribahasa: Ti dinya nya bijil, ka dinya surupna (dari situ keluar, dari situ pula tenggelamnya). 
pergi, membawa, menuju tempat kembali

kedelapan melayang di tempat pulang

Di sini Mustapa merangkai puisinya dengan menggunakan metafor yang melambangkan kembalinya diri ke kesejatian setelah mengembara menjadi manusia melalui peribahasa kebo mulih pakandangan. ${ }^{99}$ Kembalinya kesejatian ditandai dengan memotong kerbau atau sifat kemanusiaan agar tidak mengembara lagi. Karenanya setelah melewati alam tujuh yang teguh, lalu kedelapan tempat kembali. Martabat tujuh yang sudah dilalui manusia berujung pada siklus kembalinya manusia ke tempat semula. Sebagaimana kerbau, tempat kembalinya di padang rumput. Kerbau bermalam di kerbau. Alam lahir manusia kembali pada alam lahirnya. Rasa kesejatian manusia kembali pada Tuhan. Di sini, ia mengalami sirna pangawulan rasa (fana') dalam dirinya sendiri. Meleburnya Tuhan dengan rasa, rasa dengan objeknya (Tuhan). Tinggallah diri Tuhan menyendiri. Mustapa merasa sudah lelah melewati gradasi alam tujuh (ahadiyat, wahdat, wahidiyat, alam arwah, alam misal, alam ajsam, insan kamil). Kini ia sedang berada di alam kedelapan. Pergi menuju tempat pulang. Di alam kedelapan, ia merasa melayang di alam pemulangan, alam tempat kembali.

\section{Metafor Martabat Tujuh}

Tidak hanya metafor tubuh (balung, daging, sungsuam, getih) atau ungkapan Sunda: "cat mancat ka bale pulang, munding mulih pakandangan,"

99 Kebo mulih pakandangan (kerbau kembali ke kandang), maksudnya diri kembali ke asal. Bandingkan dengan mulih $\mathrm{ka}$ jati, mulang $\mathrm{ka}$ asal, lihat Ajip Rosidi, Babasan \& Paribasa, Kabeungharan Basa Sunda (Bandung: Kiblat, 2005), hlm. 118.
Mustapa menggunakan banyak metafor lain untuk menggambarkan perjalanan pulang ke alam kesejatian tempat ia berasal. Metafor yang digunakan umumnya terkait dengan alam Sunda, tempat Mustapa tinggal dan mengarang tembang. Ia misalnya menggunakan metafor makanan 'rujak lada sambarana' (rujak pedas bumbunya) 'malingping tujuh lamping' (menyusuri tujuh bukit), mandi di tujuh leuwi, janabat tujuh wahangan (mandi di tujuh kali, mandi junub di tujuh sungai), dan banyak lainnya.

Dalam Kinanti $\mathrm{Nu}$ Pengkuh di Alam Tuhu (Cod. Or. 7873), Mustapa menyatakan bahwa ketujuh martabat alam spiritual tersebut tidaklah terpisah satu sama lain. Ia meminjam metafor makanan orang Sunda, rujak. Ia menggunakannya sebagai gambaran proses mencampur dan meracik ketujuh martabat tersebut dalam dirinya. Ia menggambarkan bagaimana menikmati martabat alam tujuh ibarat menikmati rujak. Ia terdiri dari berbagai campuran buah-buahan dengan tingkat kepedasan tertentu. Enaknya dinikmati saat tengah hari sesudah makan siang. Ibarat martabat alam tujuh yang dinikmati oleh mereka yang sudah cukup berbudi. Kenikmatan ini dirasakan hingga menjelang sore, menjelang ujung usia berakhir.

\section{Tepi ka martabat tujuh}

Diracik dirucak-racik

Rujak lada sambarana

Dahareun geus sisip budi

Gahar di tengah poena

Walagri tepi ka burit. ${ }^{100}$

100 Haji Hasan Mustapa, Kinanti Nu Pengkuh di Alam Tuhu (S. 96 Or. 7873 N.5), bertitimangsa 10 Agustus 1901, 28 halaman. Ditranskripsi oleh Wiraatmaja dalam Aji Wiwitan Gendingan Dangding Sunda Jilid III. Ditranskripsi ulang dalam Iskandarwassid, dkk., Naskah Karya Haji Hasan Mustapa, hlm. 38. 
Sampai ke martabat tujuh

Diracik dengan teliti

Rujak pedas bumbunya

Makanan sesudah habis budi

Segar di tengah hari

Sehat sampai sore hari

\section{Dalam Kinanti Kacatur Martabat}

Tujuh yang dimuat dalam karya prosanya, Aji Wiwitan Martabat Tujuh, Mustapa juga menggambarkan bagaimana tujuh martabat alam itu dihimpun dan diracik. Semuanya bercampur dalam diri manusia (insan kamil), karena satu sama lain saling berhubungan. Tak hilang satupun, tiada kurang kurang tiada lebih. Tergantung salik (pengamal suluk) apakah ia bisa meraciknya untuk mencapai martabat manusia sejati (insan kamil).

1. Kacatur martabat tujuh,

tujuhna dipiriwinci, teu karasa ngarujakna, marukan di hiji-hiji, hiji misah ti kadua, unggal hiji taya bukti.

Diceritakan martabat tujuh, tujuhnya dirinci, tak terasa mencampurnya, dikira dipisah satu-satu, satu terpisah dari kedua, tiap satu tiada bukti.

2. Puguh katujuhna bukur, bukur hiji kuma hiji, dirujak jadi manusa, sahiji asaling jati, jati di rasa pangrasa, mukti teu kurang teu leuwih.

Ternyata ketujuhnya mewujud, wujud satu tergantung yang satunya, dicampur jadi manusia (insan), satu asalnya kesejatian, sejati di rasa,

cukup tak kurang tak lebih.

3. Leuwih matak langguk tangtung, kurang matak kurunyinyi, rasa nyiar pamuntangan, tandaning henteu walagri, tacan sirna lalugina, sulit ati taya budi. ${ }^{101}$

Lebih akibatnya kelebihan, kurang akibatnya kerempeng, rasa mencari tempat bergantung, tandanya tiada sempurna, belum hilang rasa tenang, sulit hati tiada budi.

Hal yang tak jauh berbeda digambarkannya dalam Kinanti Jung Indit Deui ti Bandung. Ia menggambarkan bagaimana meracik martabat tujuh merupakan upaya seorang manusia yang mau berusah payah sebelum mengalami penyatuan eksistensi. Dalam Kinanti Ngelmu Suluk Isuk-isuk, Mustapa menggambarkan bahwa upaya yang susah payah dalam mengikuti martabat tujuh ini dialaminya meski sampai harus melewati rasa pusing seperti berputar-putar. Ia mengalaminya sambil menembangkan lagu Kinanti mengarungi ketenangan hati.

\section{$314 / 415$}

\section{Hiji di martabat tujuh}

diracik jelema hiji

jelema nu sahayuna

daék indit daék cicing

daék susah daék betah

101 Haji Hasan Mustapa, Adji Wiwitan Martabat Tudjuh, hlm. 66-67. Ajip Rosidi, Haji Hasan Mustapa jeung Karya-karyana, hlm. 307-308. 
saméméh kalandi hiji. ${ }^{102}$

Satu di martabat tujuh

dicampur manusia satu

manusia yang semaunya

mau pergi mau diam

mau susah mau betah

sebelum disebut satu

Nalutur martabat tujuh

jumpalik tilu jumpalik

geus lanjung lalaganjungan

bari nembangkeun kinanti

tembang rasa papaésan

rujuk mutmainnah ati ${ }^{103}$

Ikuti martabat tujuh

berguling tiga putaran

sudah pusing berputar-putar

sambil menembang kinanti

tembang rasa menghibur

${ }^{102}$ Haji Hasan Mustapa, Kinanti Jung Indit Deui ti Bandung (S. 100 Or. 7877 N.4), bertitimangsa 17 Juni 1901, 29 halaman. Ditranskripsi oleh Wiraatmadja dalam Aji Wiwitan Gendingan Dangding Sunda Jilid III. Ditranskripsi ulang dalam Iskandarwassid, dkk., Naskah Karya Haji Hasan Mustapa, hlm. 151 dan 168.

${ }^{103}$ Haji Hasan Mustapa, Ngelmu Suluk Isuk-isuk (S. 101 Or. 7878 N.2), bertitimangsa 21 Mei 1901, 43 halaman. Ditranskripsi oleh Wiraatmaja dalam Aji Wiwitan Gendingan Dangding Sunda Jilid III. Ditranskripsi ulang dalam Iskandarwassid, dkk., Naskah Karya Haji Hasan Mustapa, hlm. 410. rujuk ketenangan hati

Metafor pencarian kesejatian melalui martabat tujuh lainnya adalah menggunakan sungai dan bukit (gunung). Mustapa menyebut pamulangan sawalungan, malingping tujuh lamping. Sebuah gambaran perjuangan tak kenal lelah dalam menempuh spiritualitas, pulang menuju sumber keberangkatan semula. Mustapa mengungkapkan hal ini dalam naskah Sinom Cat Mancat ka Bale Pulang (Or. 7876):

\section{Pamulangan sawalungan} geus malingping tujuh lamping kadalapan rorok lemah lemah putih urut indit kari mandita mukti lembur di galudra ngupuk panguprukan sorangan pangatik basa keur leutik suka betah wedalan ti Pajajaran ${ }^{104}$

Tempat pulang sehilir sungai tujuh sisi bukit telah disusuri kedelapan mengurus tanah tanah putih jejak bepergian tinggal mandita senang berbahagia kampung di galudra ngupuk ${ }^{105}$ tempat banyak belajar sendiri tempat mendidik ketika kecil senang betah lahir di Pajajaran

Mustapa menyebutkan bahwa tempat pemulangan ke kesejatian itu bak sehilir sungai. Gambaran kesejatian yang

104 Haji Hasan Mustapa, Sinom Cat Mancat ka Bale Pulang (S. 99 Or. 7876 N.7), bertitimangsa 7 Februari 1901, 38 halaman. Ditranskripsi oleh Wiraatmaja dalam Aji Wiwitan Gendingan Dangding Sunda Jilid IV.

105 Galudra ngupuk: sebutan untuk tempat yang makmur, di lingkung gunung dan tiada kekurangan air. 
mengalir ke satu tujuan. Setelah menyusuri tujuh bukit alam martabat tujuh. Kini di alam kedelapan, Mustapa bergumul dengan tanah putih jejak semula di mana ia berasal. Gambaran alam pemulangan ke alam kesejatian (tanah putih) sebagaimana jejak dahulu ketika ia pertama diciptakan. Menyusuri lamping bukit menggambarkan upaya yang tidak mudah dalam menempuh martabat rohani alam martabat tujuh. Di tempat lainnya ia menyebut dengan "mipir bukit palasari, tanjakan maraga cinta" ketika menafsirkan kata 'aqabah (tanjakan) dalam QS. Al-Balad [90]: 10$20 .^{106}$ Upaya yang susah itu digambarkannya juga dengan upaya keras kecebong (buruy) sebelum berubah menjadi katak. ${ }^{107}$

Kini di alam martabat kedelapan, ia hidup mandita, layaknya pandita yang senang dan bahagia dengan memperkaya ruhani dan menghindari godaan duniawi. Mustapa menggambarkannya layaknya hidup di galudra ngupuk, sebuah daerah yang makmur dengan tanah dan air yang subur. Di sini tempat belajar dan dididik sejak kecil. Ia merasa senang dan betah. Sebuah daerah tempat dirinya terlahir. Galudra ngupuk itu tiada lain adalah alam Pajajaran. Alam Sunda tempat ia berasal dan menempuh kehidupan.

Dalam bait lainnya di naskah yang sama, Mustapa menggunakan metafor mandi di sungai untuk menggambarkan perjalanan pendakian di alam martabat tujuh tersebut:

\section{1. /7v/Sorangan nu kabonganan geus mandi di tujuh leuwi janabat tujuh wahangan}

106 Haji Hasan Mustapa, Adji Wiwitan Petikan Ajat Kur'an Sutji, hlm. 34; Ajip Rosidi, Haji Hasan Mustapa jeung Karya-karyana, hlm. 422. Artinya: Menepi bukit palasari, jalan mendaki daerah mar(a)gacinta.

107 Jajang A Rohmana, "Sundanese Sufi Literature," hlm. 317. suci nyucikeun Gusti

ngaberesihan diri

geus teguh beunang wawasuh

moyan di kadalapan

bari ngahariring gending

aduh biyang sirna bagja kamayangan

Dirinya sendiri yang kena akibatnya

sudah mandi di tujuh kali

junub di tujuh sungai

suci mensucikan Gusti

membersihkan diri

sudah teguh hasil bersih-bersih

berjemur di alam kedelapan

sambil bersenandung tembang

aduh biyung hilang (fanā), teramat bahagia

Mustapa menyatakan bahwa dirinya merasa sudah mandi di tujuh kali, sudah junub di tujuh sungai. Gambaran perjalanan manusia yang sudah membersihkan dirinya di alam martabat tujuh secara sempurna. Ia suci dan mensucikan alam kegustiannya dan membersihkan dirinya hingga mencapai puncak alam insan kamil. Lalu setelah betul-betul bersih, ia berjemur (moyan) di bawah sorot cahaya alam kedelapan (alam mandita/jatnika), sambil bersenandung puisi tembang, "aduh biyung, hilang alam manusia (fanā') betapa bahagianya," demikian ujarnya. Mustapa kiranya menambah satu alam setelah melampaui martabat tujuh, yakni alam kedelapan, alam mandita dalam suasana fana' penuh kebahagiaan.

\section{Penutup}

Uraian di atas menunjukkan kreatifitas tasawuf lokal Sunda tentang martabat tujuh dalam dangding Mustapa. Sebuah tafsir kreatif atas ajaran dalam Tuhfah yang dijejakkan dalam alam budaya Sunda. Kiranya ini menguatkan asumsi kuatnya pengaruh karya Al-Burhanfuri tersebut dalam 
jaringan tradisi intelektual Islam Nusantara. Ia menyebar seiring dengan proses Islamisasi Nusantara yang banyak dipengaruhi ajaran sufistik. Mustapa berada dalam arus besar tradisi tasawuf Nusantara tersebut dengan tanpa meninggalkan latar budaya Sundanya. Ajaran martabat tujuh diserap dan diartikulasikan ke dalam karya sastra Sunda dangding dengan ungkapan dan metafor alam Sunda yang sangat kaya. Ia berhasil melakukan indigenisasi ajaran Islam ke dalam khasanah budaya Sunda dengan menggunakan dangding sebagai wadahnya. Sebuah bukti kuat kreatifitas tasawuf lokal di Nusantara.

\section{Bibliografi}

\section{Manuskrip}

Mustapa, Haji Hasan. Kinanti $\mathrm{Nu}$ Pengkuh di Alam Tuhu, Cod. Or. 7873. 10 Agustus 1901. UB Leiden University.

Kinanti Tutur Teu Kacatur Batur, Cod. Or. 7875. 16 Agustus 1901. UB Leiden University. - Sinom Cat Mancat ka Bale Pulang, Cod. Or. 7876. 7 Februari 1901. UB Leiden University. Kinanti Kidung pucuk mega mendung, Cod. Or. 7878. UB Leiden University.

Kinanti Ngelmu Suluk Isukisuk, Cod. Or. 7878. 21 Mei 1901. UB Leiden University. Arabic Letters from Bandung (Correspondence with Snouck Hurgronje), 1911-1923, Cod. Or. 8952, 21 September 1907, UB Leiden University.

\section{Buku dan Artikel}

'Abd Al-Jabbar, 'Umar. Siyar wa Tarajim Ba'dh 'Ulama'ina fi AlQarn al-Rabi' 'Asyr li al-Hijrah (Jeddah: Mamlakah al'Arabiyyah al-Su'udiyyah, 1403 H/1982 M), cet. ke-3.

Abdurrahman, Agus. "Martabat Tujuh Haji Hasan Mustapa," Skripsi, IAIN Sunan Gunung Djati Bandung, 2000.

Ali, Mufti. "A Study of Hasan Mustafa's Fatwa: It is Incumbent upon the Indonesian Muslims to be Loyal to the Dutch East Indies Government," Journal of the Pakistan Historical Society, April 2004, Vol. 52 Issue 2.

Ali, Yunasril. Manusia Citra Ilahi, Pengembangan Konsep Insan Kamil Ibn 'Arabi oleh al-Jili (Jakarta: Paramadina, 1997).

Al-Attas, Syed Muhammad Naguib. The Mysticism of Hamzah Fansuri. Kuala Lumpur: University of Malaya Press, 1970.

Azra, Azyumardi. The Origins of Islamic Reformism in Southeast Asia: Networks of Malay-Indonesian and Middle Eastern 'Ulama'' in the seventeenth and eighteenth centuries, Honolulu: ASAAAllen \& Unwin and University of Hawai'i Press, 2004.

Bradley, Francis R. "Sheikh Da'ud alFatani's Munyat al-Musalli and The Place of Prayer in 19thCentury Patani communities," Indonesia and the Malay World, DOI:10.1080/13639811.2013.798 072.

Bruinessen, Martin van. Tarekat Naqsabandiyah di Indonesia,Survey Historis, Geografis dan Sosiologis, Bandung: Mizan, 1992.

Burhanudin, Jajat. Islamic Knowledge, Authority and Political Power: 
The 'Ulama in Colonial Indonesia, Leiden University, 2007.

Al-Bustomi, Ahmad Gibson. Filsafat Manusia Sunda: Kumpulan Esai HHM, Teosofi dan Filsafat, Bandung: Skylart Publisher, 2012.

Christomy, Tommy. "Shattariyah Tradition in West Java: the Case of Pamijahan," Studia Islamika, Vol. 8, No. 2, 2001.

. Signs of the Wali: Narratives at the Sacred Sites in Pamijahan, West Java. Canberra: ANU E Press, 2008.

Danasasmita, Ma'mur. Wacana Bahasa dan Sastra Sunda Lama (Bandung: STSI Press, 2001).

Daudy, Ahmad. Allah dan Manusia dalam Pandangan Nuruddin AlRaniry, Jakarta: CV. Rajawali Press, 1983.

Drewes, G. "Javanese Poems dealing with or attributed to the Saint of Bonan, Bijdragen tot de Taal-, Land- en Volkenkunde 124 (1968), No: 2, Leiden.

Ekadjati, Edi S. Naskah Sunda. Inventarisasi dan Pencatatan. Bandung: Lembaga Penelitian Unpad-The Toyota Foundation, 1988.

- Empat Sastrawan Sunda Lama, Jakarta: Depdikbud, 1994.

Fathurahman, Oman. Tarekat Syattariyah di Minangkabau. Jakarta: Prenada Media, EFEO, PPIM, KITLV, 2008.

"Ithaf al-Dhaki by Ibrahim Al-

Kurani: A Commentary of Wahdat al-Wujud for Jawi Audience," Archipel 81, Paris, 2011.

"Sejarah Pengkafiran dan Marginalisasi Paham Keagamaan di Melayu dan Jawa," Analisis, Vol. XI, No. 2, Desember 2011. Ithaf Al-Dhaki, Tafsir

Wahdatul Wujud bagi Muslim Nusantara, Bandung: Mizan, 2012.

Hermansoemantri, Emuch. Sajarah Sukapura, Sebuah Telaah Filologis, Disertasi Universitas Indonesia Jakarta, 1979.

Hurgronje, C. Snouck. The Achehnese, 2 Volumes, Leiden: Brill, 1906. . Mekka in the Latter Part of the 19th Century, trans. J.H. Monahan with an introduction by Jan Just Witkam. Leiden: Brill, 2007.

Hurgronje, C. Snouck. The Achehnese, 2 Volumes, Leiden: Brill, 1906.

Ibn 'Arabi, Futuhat al-Makkiyyah, Tahqiq Uthman Yahya, Kairo: Al-Hay'at al-Misriyyah al'Ammah li al-Kitab, 1972.

Iskandar, Mohammad. Para Pengemban Amanah, Pergulatan Pemikiran Kiai dan Ulama di Jawa Barat, 1900-1950 (Yogyakarta: Mata Bangsa, 2001).

Iskandarwassid et.al., Naskah Karya Haji Hasan Mustapa, Bandung: Proyek Sundanologi, 1987.

Jahroni, Jajang. "The Life and Mystical Thought of Haji Hasan Mustafa (1852-1930)," Thesis, Leiden University, 1999.

Al-Jili, 'Abdul Karim. Al-Insan al-Kamil fi Ma'rifat al-Awa'il wa alAwakhir, Beirut: Dar al-Fikr, t.th.

Johns. A.H. The Gift Adressed to the Spirit of the Prophet, Canberra: Center of Oriental Studies A.N.U, 1965.

. "Islam in Southeast Asia: Reflections and New Directions," Indonesia, 19, 1975. 
"Reflections on the Mysticism of Shams al-Din al-Samatra'i (1550?-1630), dalam Jan van der Putten and Mary Kilcline Cody ed., Lost Times and Untold Tales from the Malay World, Singapore: NUS Press, 2009.

Kaptein, Nico. "Sayyid Uthman On the Legal Validity of Documentary Evidence," Bijdragen tot de Taal-, Land- en Volkenkunde 153 (1997), no: 1, Leiden.

Kartini, Tini, et.al., Biografi dan Karya Pujangga Haji Hasan Mustapa, Jakarta: Pusat Pembinaan dan Pengembangan Bahasa Depdikbud Jakarta, 1985.

Kraus, Werner. "The Shattariya Sufi Brotherhood in Aceh," dalam Arndt Graf et.al, Aceh History, Politics and Culture, Singapore: Iseas, 2010.

Laffan, Michael Francis. Islamic Nationhood and Colonial Indonesia, The Umma below the Winds (London-New York: Routledge Curzon, 2003).

"New Turn to Mecca:

Snapshots of Arabic Printing and

Sufi Networks in Late 19th Century Java," Revue des mondes musulmans et de la Mediterranee, 124 (2), 2008.

. The Makings of Indonesian

Islam, Orientalism and the Narration of a Sufi Past, Princeton: Princeton University Press, 2011.

Lubis, Nina H. Kehidupan Menak Priangan 1800-1942 (Bandung: Pusat Informasi Kebudayaan Sunda, 1998).

Mas'ud, Abdurrahman Mas'ud, Intelektual Pesantren: Perhelatan Agama dan Tradisi, Yogyakarta: LkiS, 2004.
Millie, Julian. "Arriving at the Point of Departing, Recent Additions to the Hasan Mustapa Legacy," BKI 170 (2014).

Moriyama, Mikihiro. Semangat Baru: Kolonialisme, Budaya Cetak dan Kesastraan Sunda Abad ke-19, trans. Suryadi (Jakarta: KPG, 2005).

Mustapa, Haji Hasan. Adji Wiwitan Martabat Tudjuh, Kenging ngumpulkeun sarta ngatur Wangsaatmadja sareng para panitiana, n.p. n.d. . Aji Wiwitan Gelaran Sasaka di Kaislaman, Kenging ngumpulkeun sarta ngatur Wangsaatmadja sareng para panitiana, n.p. n.d. Bab Adat ${ }^{2}$ Oerang Priangan Djeung Oerang Soenda Lian ti Eta, Ditjitakna di kantor tjitak Kangdjeng Goepernemen di nagara Batawi, 1913.

Qur'anul Adhimi Adji Wiwitan Qur'an Sutji, kenging ngumpulkeun Wangsaatmadja, Bandung 7 Juli 1920. Dangding Djilid Anu Kaopat, stensilan kenging ngusahakeun Ajip Rosidi, Tjihideung, Oktober 1960.

- Gendingan Dangding Sunda Birahi Katut Wirahmana Djilid A (Bandung: Jajasan Kudjang, 1976).

. Balé Bandung. Bandung: Rahmat Cijulang, 1984.

- Seri Guguritan Haji Hasan Mustapa (Asmarandana $\mathrm{Nu}$ Kami, Kinanti Kulu-kulu, Sinom Wawarian, Dangdanggula Sirna Rasa, Sinom Barangtaning Rasa) (Bandung: Kiblat, 2009).

Muthalib, Abdul. "The Mystical Thought of Muhammad Nafis Al-Banjari: An Indonesian Sufi 
of the Eighteenth Century," Thesis, McGill University Montreal Canada, 1995.

Mu'jizah, Martabat Tujuh: Edisi Teks dan Pemaknaan Tanda serta Simbol, Jakarta: Penerbit Djambatan dan Yayasan Naskah Nusantara, 2005.

Nasution, Harun. Falsafah dan Mistisisme dalam Islam, Jakarta: Bulan Bintang, 1973.

Nicholson, Reynold A. The Mystics of Islam, (Indiana: World Wisdom, 2002).

Quzwain, Muhammad Chatib. Mengenal Allah: Suatu Studi Mengenai Ajaran Tasawuf Syeikh Abdus Samad Al-Falimbani, Jakarta: Bulan Bintang, 1983.

Ricklefs, M. C. Mengislamkan Jawa, terj. FX. Dono Sunardi dan Satrio Wahono, Jakarta: Serambi, 2013.

Rohmana, Jajang A. 'Sundanese Sufi Literature and Local Islamic Identity: A Contribution of Haji Hasan Mustapa's Dangding.' Journal Al-Jamiah, Vol. 50, No. 2.

. "Makhtutat Kinanti [Tutur teu Kacatur Batur]: Tasawwuf al"Alam al-Sundawi 'ind al-Hajj Hasan Mustafa (1852-1930),' Studia Islamika, Vol. 20, No. 2, 2013.

Ronkel, PH. S. Van. "Aanteekeningen over Islam en Folklore in Westen Midden Java, Uit Het Reisjournaal van Dr. C. Snouck Hurgronje," BKI 101 (1942).

Rosidi, Ajip. Ngalanglang Kasusastran Sunda, Jakarta: Pustaka Jaya, 1983.

Haji Hasan Mustapa jeung Karya-karyana, Bandung: Pustaka, 1989.
Hurip Waras, Dua

Panineungan, Bandung: Kiblat Buku Utama, 2001, cet. ke-2. ed. Ensiklopedi Sunda, Alam, Budaya, dan Manusia (Jakarta: Pustaka Jaya, 2003).

- Babasan \& Paribasa, Kabeungharan Basa Sunda

(Bandung: Kiblat, 2005). . Mencari Sosok Manusia Sunda (Bandung: Pustaka Jaya, 2010).

Ruhaliah, "Analisis Struktur dan Nilai Budaya Naskah Sunda," Jurnal Sonagar, Vol. 2, 2004.

Rusyana, Yus. dan Ami Raksanegara. Puisi Guguritan Sunda, Jakarta: Pusat Pembinaan dan Pengembangan Bahasa Depdikbud, 1980

Santrie, Aliefya M. "Martabat Alam Tujuh, Suatu Naskah Mistik Islam dari Desa Karang Pamijahan," dalam Ahmad Rifa'i Hasan, ed., Warisan Intelektual Islam Indonesia (Bandung: Mizan, 1992), cet. ke-3.

Setiawan, Hawe. "Dangding Mistis Haji Hasan Mustapa," Makalah Seri Kuliah Umum Islam dan Mistisime Nusantara di Teater Salihara, 4 Agustus 2012.

Shah, Idries. The Sufis (London: The Octagon Press, 1977).

Simuh. Mistik Islam Kejawen Raden Ngabehi Ranggawarsita. Jakarta: UI-Press, 1988. "Aspek Mistik Islam Kejawen dalam 'Wirid Hidayat Jati,' dalam Ahmad Rifa'i Hasan, ed., Warisan Intelektual Islam Indonesia Telaah atas KaryaKarya Klasik, Bandung: Mizan, 1992.

Soebardi, S. "Santri-Religious Elements as Reflected in the Book of Centini," Bijdragen tot de Taal-, 
Land-en Volkenkunde 127 (1971), No: 3, Leiden.

. The Book of Cebolek. Leiden: KITLV-The Hague-Martinus Nijhoof, 1975.

Wendy Solomon, "Text and Personality: Ajip Rosidi in Search of Haji Hasan Mustapa," Indonesia Circle. School of Oriental \& African Studies. Newsletter, 14:41, 1986.

Steenbrink, Karel. "Qur'an Interpretations of Hamzah Fansuri (CA. 1600) and Hamka (1908-1982): A Comparison," Studia Islamika, Vol. 2, No. 2, 1995.

Suryalaga, H.R. Hidayat. Filsafat Sunda, Sekilas Interpretasi Folklor Sunda, Bandung: Yayasan Nur Hidayah, 2010.

Suryaningsih, Iin. "Al-Haqiqah alMuwāfaqah li al-Shari'‘ah: alTașāluh bayn al-Tașawwuf wa al-Shari' ah bi Nusantara fí alQarn al-Sādis "Ashr al-Milādì,"
Studia Islamika, Vol. 20, No. 1, 2013.

Al-Taftazani, Abu Al-Wafa' AlGhanimi. Sufi dari Zaman ke Zaman, terj. Ahmad Rofi' 'Utsmani, (Bandung: Pustaka, 1987).

Trimingham, J. Spencer. The Sufi Orders in Islam, Oxford: Clarendon Press, 1977.

Yunus, Abdul Rahim. "Nazariyat Martabat Tujuh fi Nizam alMamlakah al-Butaniyyah," Studia Islamika, Vol. 2, No. 1, 1995.

Zoetmulder, P.J. Manunggaling Kawula Gusti, Pantheisme dan Monisme dalam Sastra Suluk Jawa. terj. Dick Hartoko. Jakarta: Gramedia Pustaka Utama, 1991.

\section{Majalah}

"Syair Mistis Bagawan Sirna Dirasa," Tempo, 16 September 2012. 